\title{
Understanding Materials Characteristics of Palladium Lanthanide Cermet Wires as a Mimic of Californium Wire Production
}

Approved for public release.

Distribution is unlimited.
Samantha K. Cary Laetitia H. Delmau Julie G. Ezold Shannon M. Mahurin Richard Mayes

October 2020 


\title{
DOCUMENT AVAILABILITY
}

Reports produced after January 1, 1996, are generally available free via US Department of Energy (DOE) SciTech Connect.

Website www.osti.gov

Reports produced before January 1, 1996, may be purchased by members of the public from the following source:

\author{
National Technical Information Service \\ 5285 Port Royal Road \\ Springfield, VA 22161 \\ Telephone 703-605-6000 (1-800-553-6847) \\ TDD 703-487-4639 \\ Fax 703-605-6900 \\ E-mail info@ntis.gov \\ Website http://classic.ntis.gov/
}

Reports are available to DOE employees, DOE contractors, Energy Technology Data Exchange representatives, and International Nuclear Information System representatives from the following source:

Office of Scientific and Technical Information

PO Box 62

Oak Ridge, TN 37831

Telephone 865-576-8401

Fax 865-576-5728

E-mail reports@osti.gov

Website http://www.osti.gov/contact.html

This report was prepared as an account of work sponsored by an agency of the United States Government. Neither the United States Government nor any agency thereof, nor any of their employees, makes any warranty, express or implied, or assumes any legal liability or responsibility for the accuracy, completeness, or usefulness of any information, apparatus, product, or process disclosed, or represents that its use would not infringe privately owned rights. Reference herein to any specific commercial product, process, or service by trade name, trademark, manufacturer, or otherwise, does not necessarily constitute or imply its endorsement, recommendation, or favoring by the United States Government or any agency thereof. The views and opinions of authors expressed herein do not necessarily state or reflect those of the United States Government or any agency thereof. 
Isotope and Fuel Cycle Technology Division

\title{
UNDERSTANDING MATERIALS CHARACTERISTICS OF PALLADIUM LANTHANIDE CERMET WIRES AS A MIMIC OF CALIFORNIUM WIRE PRODUCTION
}

\author{
Samantha K. Cary \\ Laetitia H. Delmau \\ Julie G. Ezold \\ Shannon M. Mahurin \\ Richard Mayes
}

October 15, 2020

Prepared by

OAK RIDGE NATIONAL LABORATORY

Oak Ridge, TN 37831-6283

managed by

UT-BATTELLE, LLC

for the

US DEPARTMENT OF ENERGY

under contract DE-AC05-00OR22725 



\section{CONTENTS}

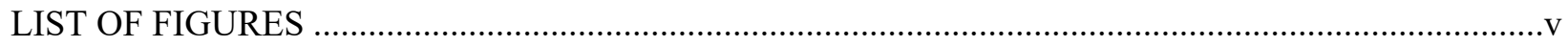

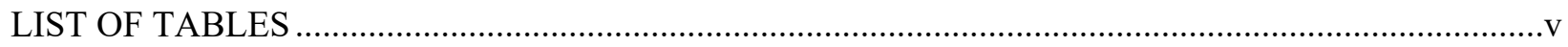

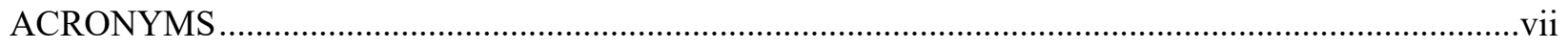

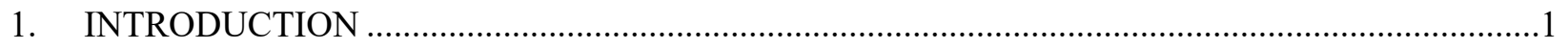

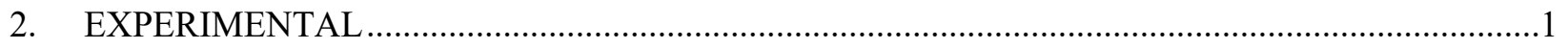

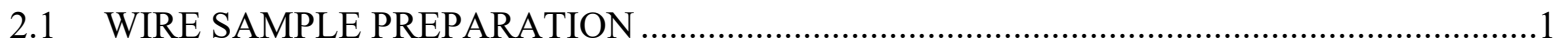

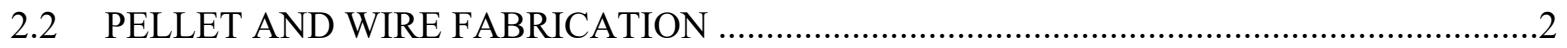

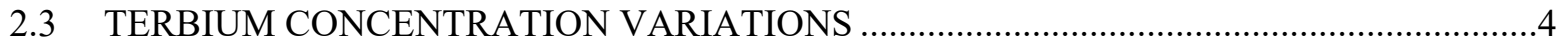

2.4 THE ADDITION OF $\alpha$-HYDROXYISO-BUTYRATE (AHIB) ….......................................

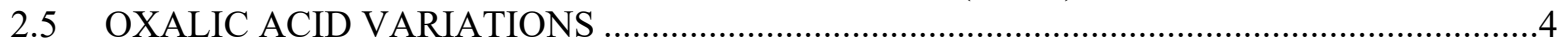

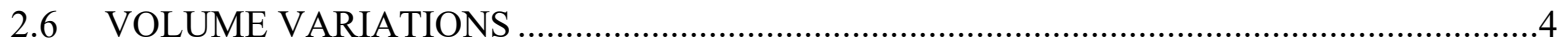

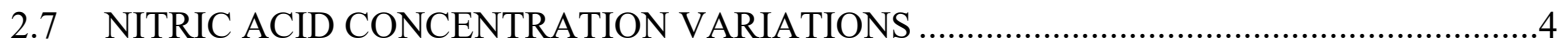

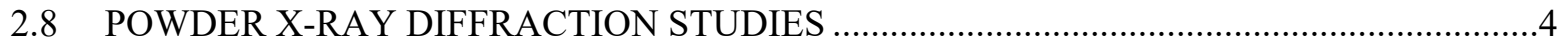

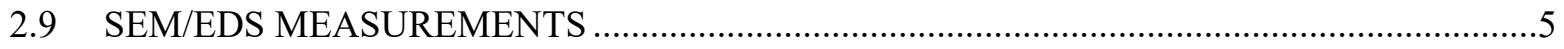

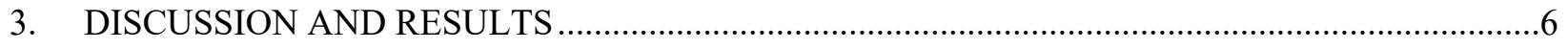

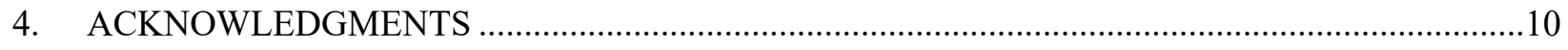

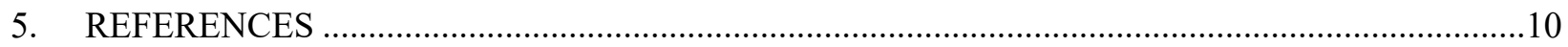

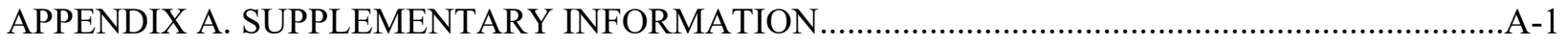





\section{LIST OF FIGURES}

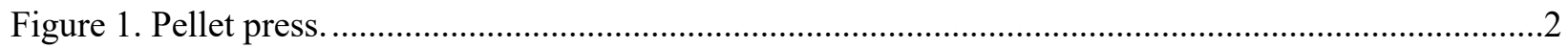

Figure 2. Images of a pressed pellet: (left) viewed from the top and (right) the side...............................

Figure 3. The temperature profile used to melt a pellet....................................................................

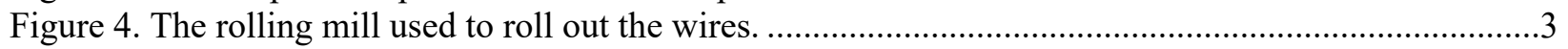

Figure 5. Blushing of a TbPd wire as a result of not being annealed in Ar. ..............................................

Figure 6. Overlaid powder patterns of TbPd material after precipitation. ................................................5

Figure 7. Scanning electron microscope (SEM) images of six different samples. .....................................5

Figure 8. Scanning electron microscope (SEM) images of a pressed pellet: (left) view of the side

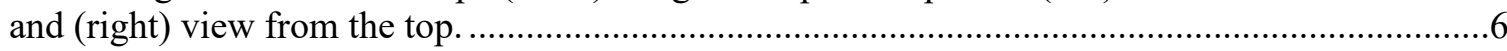

Figure 9. Scanning Electron Microscope (SEM) images of a wire being rolled out in three

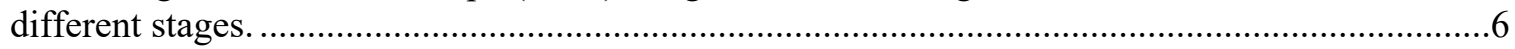

Figure 10. Several wires that have been rolled out for this study........................................................6

Figure 11. A structural drawing of the AHIB ligand. ........................................................................

Figure 12. Pd black product after calcination. …..............................................................................

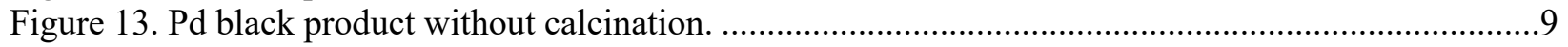

\section{LIST OF TABLES}

Table 1. Reaction conditions for the preparation of $\mathrm{PdTb}_{2} \mathrm{O}_{3}$ samples..................................................2

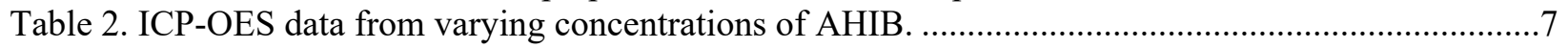

Table 3. ICP-OES data from varying volumes of nitric acid...........................................................

Table 4. ICP-OES data from varying concentrations of Tb................................................................

Table 5. ICP-OES data from varying concentrations of oxalic acid....................................................

Table 6. ICP-OES data from varying concentrations of nitric acid ...................................................... 



\section{ACRONYMS}

$\begin{array}{ll}\mathrm{AHIB} & \text { alpha-hydroxyisobutyrate (complexing agent) } \\ \mathrm{Al}_{2} \mathrm{O}_{3} & \text { aluminum oxide } \\ \mathrm{Ar} & \text { argon } \\ \mathrm{Bk} & \text { berkelium } \\ \mathrm{C} & \text { carbon } \\ \mathrm{Cf} & \text { californium } \\ \mathrm{Cf}_{2} \mathrm{O}_{3} & \text { californium oxide } \\ \mathrm{Cm} & \text { curium } \\ \mathrm{EDS} & \text { energy dispersive X-ray spectroscopy } \\ \mathrm{Es} & \text { einsteinium } \\ \mathrm{Fe} & \text { iron } \\ \mathrm{H} & \text { hydrogen gas } \\ \mathrm{He} & \text { helium } \\ \mathrm{HFIR} & \text { High Flux Isotope Reactor } \\ \mathrm{HNO} & \text { nitric acid } \\ \mathrm{ICP}-\mathrm{OES} & \text { inductively coupled plasma-optical emission spectroscopy } \\ \mathrm{Ln} & \text { lanthanide } \\ \mathrm{ORNL} & \text { Oak Ridge National Laboratory } \\ \text { pXRD } & \text { powder X-ray diffraction } \\ \mathrm{Pd} & \text { palladium } \\ \mathrm{PdO} & \text { palladium oxide } \\ \mathrm{REDC} & \text { Radiochemical Engineering and Development Center } \\ \mathrm{SEM} & \text { scanning electron microscope } \\ \mathrm{SRNL} & \text { Savannah River National Laboratory } \\ \mathrm{Tb} & \text { terbium } \\ \mathrm{Tb} \mathrm{O}_{4} \mathrm{O}_{7} & \text { terbium oxide } \\ \mathrm{Tb}\left(\mathrm{H}_{2} \mathrm{C}_{2} \mathrm{O}_{4}\right)_{\mathrm{x}} & \text { terbium oxalate } \\ \mathrm{XPS} & \text { X-ray photoelectron spectroscopy } \\ & \end{array}$





\section{INTRODUCTION}

Californium-252 (Cf-252) has been synthesized on a large scale (mg) since the 1970s for use as a portable neutron source. With a half-life of 2.645 years and a spontaneous fission fraction of $3.09 \%$, Cf-252 emits $2.31 \times 10^{12}$ neutrons/gram second [1]. Today most of the Cf-252 produced in the world is made at Oak Ridge National Laboratory (ORNL) using the High Flux Isotope Reactor (HFIR) and the Radiochemical Engineering Development Center (REDC). Because of its highly radioactive nature, all manipulations of Cf-252 need to be performed in hot cell facilities by highly trained personnel. The Cf- 252 produced at ORNL is done at the REDC, which is conveniently located next to the HFIR.

Cf-252 is sold as bulk wire, which has been described as palladium (Pd) metal incasing californium oxide $\left(\mathrm{Cf}_{2} \mathrm{O}_{3}\right)$. The process was developed by Mosley et al. at Savannah River Laboratory (SRL) where it was modeled after the thorium work done by Fuschillo et al. [1-2]. This process has been used since the 1970s to synthesize this unique wire, but its fundamental chemistry and materials characteristics were never openly reported [1]. Here we aim to better understand the chemistry and the materials characteristics of Cf-252 wire production for process improvements and to better our fundamental understanding of the mid-late actinides.

Though there are many challenges in working with radioactive elements such as Cf, the isotope Cf-252 is even more complicated due to its neutron emission. One challenge with neutron emission is the ability of neutrons to penetrate much deeper through materials, causing radiation damage. This makes using instrumentation to characterize the chemistry and materials properties of this process difficult. For this reason, this study will first focus on terbium $(\mathrm{Tb})$ as a surrogate for Cf. Currently $\mathrm{Tb}$ is used as a carrier or filler in $\mathrm{Cf}$ production when small amounts of $\mathrm{Cf}$ are being processed. This, along with their similar size and charge, makes $\mathrm{Tb}$ a reasonable surrogate for this study.

\section{EXPERIMENTAL}

\subsection{WIRE SAMPLE PREPARATION}

Samples of $\mathrm{PdTb}_{2} \mathrm{O}_{3}$ were prepared in a manner similar to the method reported by SRL in 1970 [1]. All the reaction conditions used to synthesize these samples are shown in Table 1. Terbium oxalate is precipitated in a large quartz tube by heating terbium nitrate $(15 \mathrm{mg}$ of $\mathrm{Tb})$ in nitric acid $(0.1 \mathrm{M})$ to $60^{\circ} \mathrm{C}$ while bubbling argon (Ar) gas through a sparge tube. It should be noted that the Ar bubbler is primarily used to mix the solution, not to purge the air from the reaction. Once at temperature, oxalic acid $(0.1 \mathrm{M}$, $15 \mathrm{~mL}$ or $1 \mathrm{M}, 3 \mathrm{~mL}$ ) is added to the Tb solution and the first precipitation occurs. Excess oxalic acid is used to ensure the precipitation of terbium oxalate $\left(\mathrm{H}_{2} \mathrm{C}_{2} \mathrm{O}_{4}\right)_{\mathrm{x}}$. Once the Tb oxalate is precipitated, hydrazine hydrate $(85 \%, 3 \mathrm{~mL})$ is added dropwise to the solution. An excess of hydrazine is necessary to oxidize the excess oxalic acid, which discourages the formation of Pd oxalate in the next step. The second precipitation is then performed by adding a soluble Pd compound (typically $0.5-0.7 \mathrm{~g}$ ) to the solution containing the $\mathrm{Tb}$ oxalate and hydrazine hydrate. This results in the precipitation of Pd black. Depending on the Pd compound used to perform this coprecipitation, different colors (black-grey), particle sizes, and possible mirroring of $\mathrm{Pd}^{0}$ are observed. The reaction is left to sit for at least 1 hour or until the reaction is producing minimal $\mathrm{H}_{2}(\mathrm{~g})$. The Ar bubbler is removed, and the solid is left to settle out of solution. The supernatant is pipetted off and saved for inductively coupled plasma-optical emission spectroscopy (ICPOES) analysis, and the solid is left at the bottom of the tube. To dry the solid, the quartz tube is placed into a tube furnace and is heated under $\mathrm{Ar}$ at $100^{\circ} \mathrm{C}$ until no more water condensation is visible on the tube (typically 2 hours). Then the furnace is heated to $200^{\circ} \mathrm{C}$ for an additional 8 hours to ensure total dryness. Once dry, the solid is annealed in a helium atmosphere containing $4 \%$ hydrogen $\left(4 \% \mathrm{H}_{2} / \mathrm{He}\right)$ at 
$700{ }^{\circ} \mathrm{C}$ for 30 minutes to convert residual $\mathrm{Tb}\left(\mathrm{C}_{2} \mathrm{O}_{4}\right)_{\mathrm{x}}$ into $\mathrm{Tb}_{2} \mathrm{O}_{3}$. After the annealing time is elapsed, the solid is allowed to cool to room temperature.

After annealing, the solid is weighed and broken up in preparation for pellet fabrication. To test whether the thermal decomposition of $\mathrm{Tb}\left(\mathrm{C}_{2} \mathrm{O}_{4}\right)_{\mathrm{x}}$ was necessary additional material was made without annealing.

Table 1. Reaction conditions for this study.

\begin{tabular}{|c|c|c|c|c|}
\hline Sample Number & Pd starting material & Pd supplier & Tb starting material & Pd:Tb ratio \\
\hline 1 & $\left(\mathrm{NH}_{3}\right)_{4} \mathrm{Pd}\left(\mathrm{NO}_{3}\right)_{2}$ & Beantown & $\mathrm{Tb}\left(\mathrm{NO}_{3}\right)_{3}(\mathrm{H} 2 \mathrm{O})_{\mathrm{x}}$ & $1: 0.01$ \\
\hline 2 & $\mathrm{~K}_{2} \mathrm{PdCl}_{2}$ & Sigma Aldrich & $\mathrm{Tb}\left(\mathrm{NO}_{3}\right)_{3}(\mathrm{H} 2 \mathrm{O})_{\mathrm{x}}$ & $1: 0.016$ \\
\hline 3 & $\left(\mathrm{NH}_{3}\right)_{4} \mathrm{Pd}\left(\mathrm{NO}_{3}\right)_{2}$ & Beantown & $\mathrm{Tb}_{4} \mathrm{O}_{7}$ & $1: 0.003$ \\
\hline 4 & $\left(\mathrm{NH}_{3}\right)_{4} \mathrm{Pd}\left(\mathrm{NO}_{3}\right)_{2}$ & Sigma Aldrich & $\mathrm{Tb}\left(\mathrm{NO}_{3}\right)_{3}(\mathrm{H} 2 \mathrm{O})_{\mathrm{x}}$ & $1: 0.005$ \\
\hline 5 & $\left(\mathrm{NH}_{3}\right)_{4} \mathrm{Pd}\left(\mathrm{NO}_{3}\right)_{2}$ & Beantown & $\mathrm{Tb}\left(\mathrm{NO}_{3}\right)_{3}(\mathrm{H} 2 \mathrm{O})_{\mathrm{x}}$ & 1:0.005 \\
\hline 6 & $\left(\mathrm{NH}_{3}\right)_{4} \mathrm{Pd}\left(\mathrm{NO}_{3}\right)_{2}$ & STREM & $\mathrm{Tb}\left(\mathrm{NO}_{3}\right)_{3}(\mathrm{H} 2 \mathrm{O})_{\mathrm{x}}$ & $1: 0.007$ \\
\hline 7 & $\left(\mathrm{NH}_{3}\right)_{4} \mathrm{Pd}\left(\mathrm{NO}_{3}\right)_{2}$ & Beantown & $\mathrm{Tb}\left(\mathrm{NO}_{3}\right)_{3}(\mathrm{H} 2 \mathrm{O})_{\mathrm{x}}$ & $1: 0.005$ \\
\hline 8 & $\left(\mathrm{NH}_{3}\right)_{4} \mathrm{Pd}\left(\mathrm{NO}_{3}\right)_{2}$ & Beantown & $\mathrm{Tb}\left(\mathrm{NO}_{3}\right)_{3}(\mathrm{H} 2 \mathrm{O})_{\mathrm{x}}$ & $1: 0.007$ \\
\hline 9 & $\left(\mathrm{NH}_{3}\right)_{4} \mathrm{Pd}\left(\mathrm{NO}_{3}\right)_{2}$ & Sigma Aldrich & $\mathrm{Sm}\left(\mathrm{NO}_{3}\right)_{3}(\mathrm{H} 2 \mathrm{O})_{\mathrm{x}}$ & $1: 0.005$ \\
\hline 10 & $\left(\mathrm{NH}_{3}\right)_{4} \mathrm{Pd}\left(\mathrm{NO}_{3}\right)_{2}$ & Beantown & $\mathrm{Tb}\left(\mathrm{NO}_{3}\right)_{3}(\mathrm{H} 2 \mathrm{O})_{\mathrm{x}}$ & $1: 0.005$ \\
\hline 11 & $\left(\mathrm{NH}_{3}\right)_{4} \mathrm{Pd}\left(\mathrm{NO}_{3}\right)_{2}$ & Beantown & $\mathrm{Tb}\left(\mathrm{NO}_{3}\right)_{3}(\mathrm{H} 2 \mathrm{O})_{\mathrm{x}}$ & $1: 3$ \\
\hline 12 & $\left(\mathrm{NH}_{3}\right)_{4} \mathrm{Pd}\left(\mathrm{NO}_{3}\right)_{2}$ & Beantown & $\mathrm{Tb}\left(\mathrm{NO}_{3}\right)_{3}(\mathrm{H} 2 \mathrm{O})_{\mathrm{x}}$ & $1: 5$ \\
\hline 13 & $\left(\mathrm{NH}_{3}\right)_{4} \mathrm{Pd}\left(\mathrm{NO}_{3}\right)_{2}$ & Beantown & N/A & no $\mathrm{Tb}$ \\
\hline 14 & $\left(\mathrm{NH}_{3}\right)_{4} \mathrm{Pd}\left(\mathrm{NO}_{3}\right)_{2}$ & Beantown & $\mathrm{Tb}_{4} \mathrm{O}_{7}$ & $1: 0.005$ \\
\hline 15 & $\left(\mathrm{NH}_{3}\right)_{4} \mathrm{Pd}\left(\mathrm{NO}_{3}\right)_{2}$ & Beantown & $\mathrm{Tb}\left(\mathrm{NO}_{3}\right)_{3}(\mathrm{H} 2 \mathrm{O})_{\mathrm{x}}$ & 1:0.005 \\
\hline 16 & $\left(\mathrm{NH}_{3}\right)_{4} \mathrm{Pd}\left(\mathrm{NO}_{3}\right)_{2}$ & Beantown & $\mathrm{N} / \mathrm{A}$ & no $\mathrm{Tb}$ \\
\hline 17 & $\left(\mathrm{NH}_{3}\right)_{4} \mathrm{Pd}\left(\mathrm{NO}_{3}\right)_{2}$ & Beantown & $\mathrm{Tb}_{4} \mathrm{O}_{7}$ & $1: 0.005$ \\
\hline 18 & $\left(\mathrm{NH}_{3}\right)_{4} \mathrm{Pd}\left(\mathrm{NO}_{3}\right)_{2}$ & Beantown & $\mathrm{Tb}\left(\mathrm{NO}_{3}\right)_{3}(\mathrm{H} 2 \mathrm{O})_{\mathrm{x}}$ & $1: 0.005$ \\
\hline 19 & $\left(\mathrm{NH}_{3}\right)_{4} \mathrm{Pd}\left(\mathrm{NO}_{3}\right)_{2}$ & Beantown & $\mathrm{Tb}\left(\mathrm{NO}_{3}\right)_{3}(\mathrm{H} 2 \mathrm{O})_{\mathrm{x}}$ & $1: 3$ \\
\hline 20 & $\left(\mathrm{NH}_{3}\right)_{4} \mathrm{Pd}\left(\mathrm{NO}_{3}\right)_{2}$ & STREM & $\mathrm{Tb}\left(\mathrm{NO}_{3}\right)_{3}(\mathrm{H} 2 \mathrm{O})_{\mathrm{x}}$ & $1: 0.005$ \\
\hline 21 & $\mathrm{~K}_{2} \mathrm{PdCl}_{2}$ & Sigma Aldrich & $\mathrm{Tb}\left(\mathrm{NO}_{3}\right)_{3}(\mathrm{H} 2 \mathrm{O})_{\mathrm{x}}$ & $1: 0.005$ \\
\hline
\end{tabular}

\subsection{PELLET AND WIRE FABRICATION}

The pellets were pressed using the hydraulic press, shown in Figure 1 , a press similar to that used in the californium wire production. A 0.172 in. die was used in the preparation of most of the pellets. For those small in size, 0.150 in. die was used instead. The die was lubricated 1 hour prior to pellet pressing with a saturated solution of stearic acid in acetone. Each pellet was pressed to 200 psi before the pressure was immediately released and then pressed to $500 \mathrm{psi}$ for 1 minute. The pellets produced had a grey/black top and bottom with metallic sides (Figure 2). This process is thought to sinter the $\mathrm{Pd}$ forming a metallic sheen on the outer edge.

The pressed pellet was then placed into a glassy carbon crucible that was nested into a larger $\mathrm{Al}_{2} \mathrm{O}_{3}$ crucible. This assembly is placed in a vertical tube furnace, and the $\mathrm{Pd}^{0}$ was melted at $1540{ }^{\circ} \mathrm{C}$. The full temperature profile is shown in Figure 3. Once cooled the pellet is weighed and measured before it was cold rolled into a wire using the

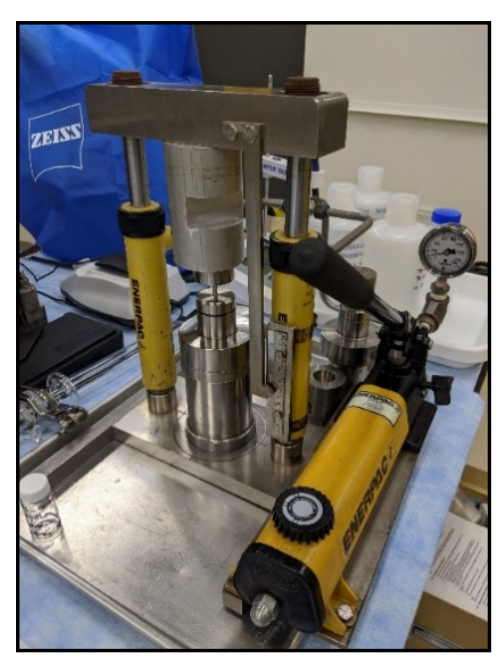

Figure 1. Hydraulic pellet press used in this study. 
rolling mill in Figure 4. The rolling mill has 16 groves which allows for a variety of different wire sizes to be produced. Between rolling in each grove, the wire is annealed at $850^{\circ} \mathrm{C}$ in Ar. It should be noted that cold rolling Pd wire without annealing causes excessive cracking and annealing in air or $\mathrm{He} / \mathrm{H}_{2}(4 \%)$ causes "Pd blushing," which is a thin layer of $\mathrm{PdO}_{2}$ seen in Figure 5, both of which should be avoided if possible. The surface oxides should be minimized to prevent $\mathrm{PdO}_{2}$ contamination in the wire, which will decrease the tensile properties of the wire increasing the possibility of breakage.
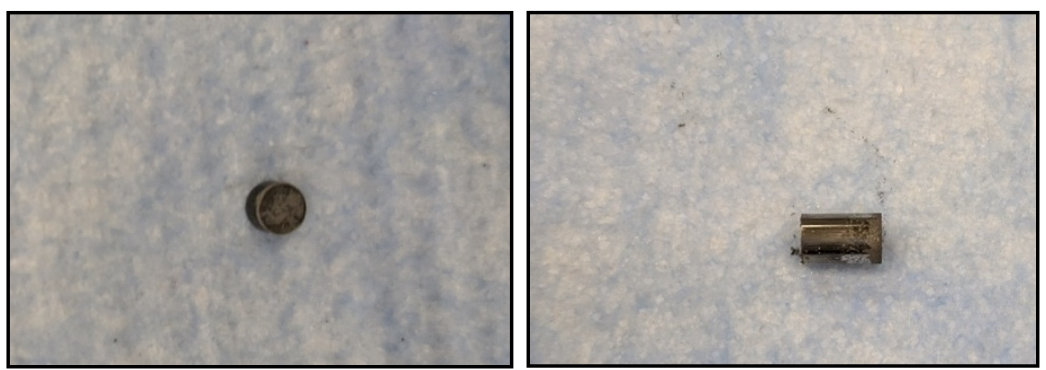

Figure 2. Images of a pressed pellet: (left) viewed from the top and (right) the side.

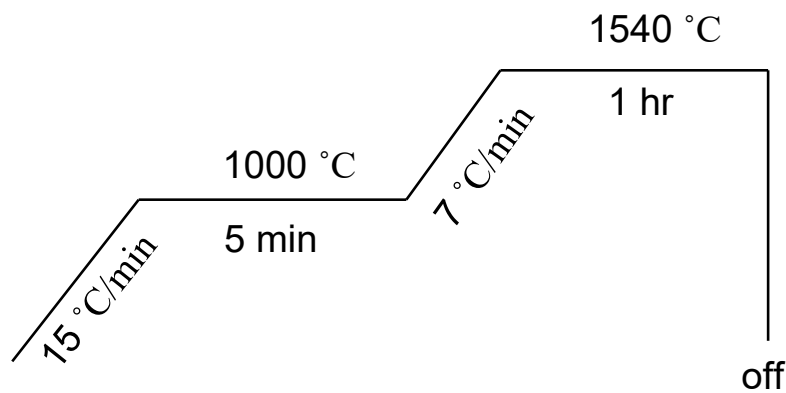

Figure 3. The temperature profile used to melt a pellet.
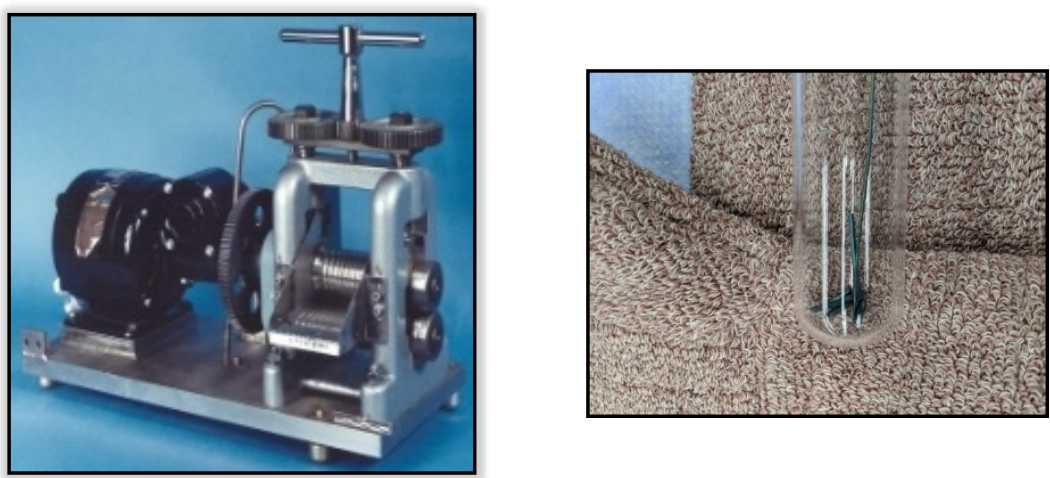

Figure 4. The rolling mill used to roll out the wires.

Figure 5. Blushing of a TbPd wire as a result of not being annealed in Ar.

After the wire was rolled out to about an inch in length, it was melted a second time with additional Pd metal. The amount of Pd metal was calculated using Equations 1 and 2 which have historically been used throughout wire production. 


$$
\begin{aligned}
& \text { Palladium Multiplier Factor }(\mathrm{PMF})=12.61 \times(\text { Diameter Needed })-0.24 \text {. } \\
& \qquad \text { Pd-metal }(\mathrm{g})=\frac{\text { Total } \mu \mathrm{g} 252 \mathrm{Cf} \text { Content }}{\mu \mathrm{g} 252 \mathrm{Cf} / \text { inch }} \times[\mathrm{PMF}]-[\text { Total Pd Present }]
\end{aligned}
$$

The temperature profile used to melt the pellet is the same as that used above and described in Figure 3. After melting, the Pd-Tb pellet is broken out of the glassy carbon crucible and then rolled out to a desired length. This length and diameter is usually determined by the activity a customer wants for Cf production. For $\mathrm{Tb}$ we chose a length of 1 in., based on a common activity used in production.

\subsection{TERBIUM CONCENTRATION VARIATIONS}

Through the years, the amount of Cf processed has varied, depending on the demand. This has led to the same process (and amounts) being used to make wire with $\mathrm{Cf}-252$ concentrations ranging from hundreds of $\mu \mathrm{g}-50 \mathrm{mg}$. Today much smaller amounts of $\mathrm{Cf}$ are used. To understand if and how this affects our yields and processes, we tested $\mathrm{Tb}$ concentrations of $2 \mathrm{mg}, 5 \mathrm{mg}, 10 \mathrm{mg}, 15 \mathrm{mg}$, and $30 \mathrm{mg}$. All samples were analyzed by ICP-OES to verify the Tb concentrations.

\subsection{THE ADDITION OF $\alpha$-HYDROXYISO-BUTYRATE (AHIB)}

AHIB is a common reagent used to separate $\mathrm{Cf}$ from its neighboring actinides (Cm, Bk, Es). If the AHIB ligand is left in solution for the oxalate precipitation, the two ligands will most likely compete for the $\mathrm{Tb}$ making reaction yields lower. To test this theory, differing concentrations of AHIB were added to solutions of $\mathrm{Tb}$. After the solution was brought to a $\mathrm{pH}$ of 1 , the reaction was heated, and the oxalic acid was added. All samples were analyzed by ICP-OES.

\subsection{OXALIC ACID VARIATIONS}

Over the years different processes have called for various amounts of oxalic acid to perform oxalic acid precipitation. The concentrations of oxalic acid used by the Cf production process have ranged from 0.1 $\mathrm{M}$ to $1 \mathrm{M}$. To optimize this process, several concentrations $(0.01 \mathrm{M}, 0.025 \mathrm{M}, 0.05 \mathrm{M}, 0.075 \mathrm{M}, 0.1 \mathrm{M}, 1$ $\mathrm{M})$ and volumes of oxalic acid were used to perform the precipitation. All samples were analyzed by ICPOES.

\subsection{VOLUME VARIATIONS}

As this process has changed over the years, so have the volumes in which the precipitation reaction takes place. Volumes ranging from $20-45 \mathrm{~mL}$ have been observed from historical data. To test if this affects the oxalate precipitation, we ran the same reaction by varying the volume from $20-45 \mathrm{~mL}$. All samples were analyzed by ICP-OES.

\subsection{NITRIC ACID CONCENTRATION VARIATIONS}

Testing small variations in acid concentration is important to understand how acid manipulates the yield for the oxalate precipitation step. Here the nitric acid concentration was varied from $0.01 \mathrm{M}$ to $0.3 \mathrm{M}$ while keeping other variables constant. One big difference that is noticeable within minutes of the oxalate precipitation is the difference in the amount of precipitate between concentrations. In general, a higher acid concentration produces less precipitate. All samples were analyzed by ICP-OES. 


\subsection{POWDER X-RAY DIFFRACTION (PXRD) STUDIES}

Powder X-ray diffraction studies were performed on the co-precipitate $\mathrm{PdTb}\left(\mathrm{C}_{2} \mathrm{O}_{4}\right)_{\mathrm{x}}$ using a PANalytical Empyrean diffractometer. Samples were prepared by placing a small amount of the co-precipitate $\operatorname{PdTb}\left(\mathrm{H}_{2} \mathrm{C}_{2} \mathrm{O}_{4}\right)_{\mathrm{x}}$ onto a quartz slide. Slight shifts between spectra can be seen when they are overlaid (Figure 6), off-sets can be a function of sample height (thickness). Difficulty arises in assigning the Pd-Tb alloy formed because the majority (by percentage) of each sample is Pd metal; therefore, identifying which Tb-Pd complexes is complicated, if even possible. This is due to the predominance of the $\mathrm{Pd}^{0}$ features in the pXRD pattern, which negate the possibility of analyzing the significantly lower intensity features of the alloy. Two additional samples of with higher ratios of $\mathrm{TbPd}_{3}$ and $\mathrm{TbPd}_{5}$ to $\mathrm{Pd}^{0}$ were synthesized in attempt to assess possible coordination complexes.

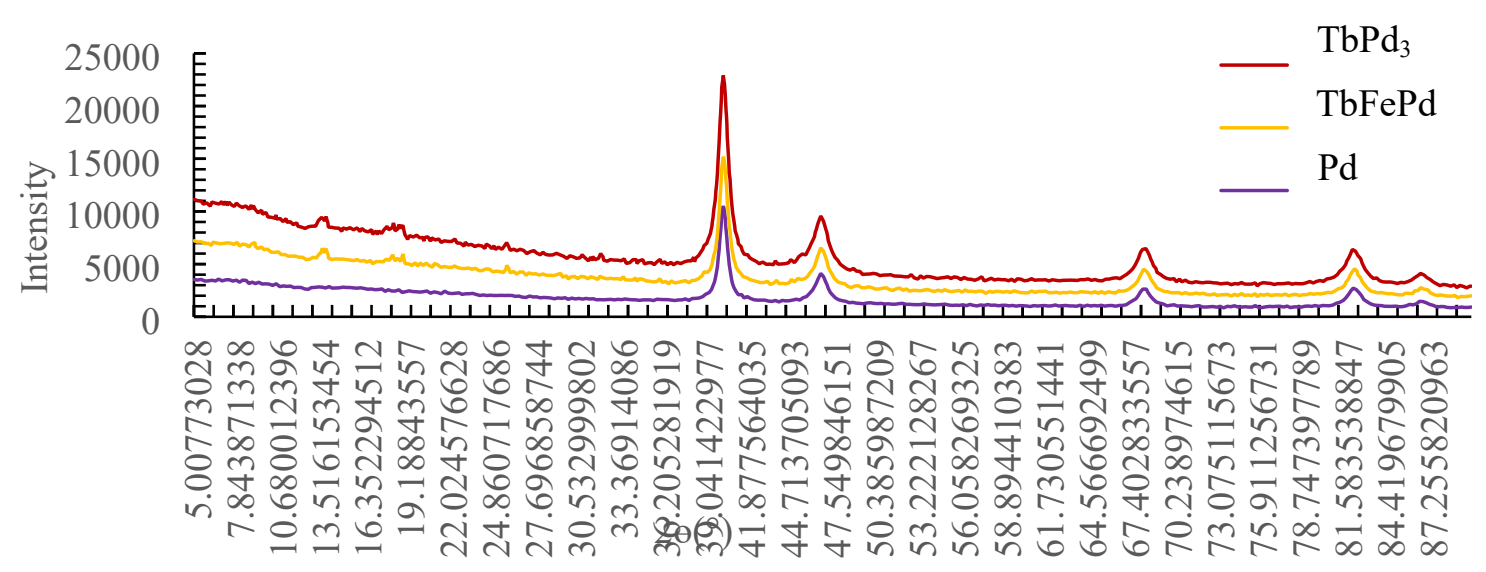

Figure 6. Overlaid powder patterns of TbPd material after precipitation.

\subsection{SEM/EDS MEASUREMENTS}

Scanning electron microscopy/energy dispersive X-ray spectroscopy (SEM/EDS) was used to examine the particle size of the coprecipitates as well as the materials properties of the pressed pellets and wires. All measurements were performed on a JOEL JSM-6060 SEM equipped with a EDAX EDS. Comparing the particles from all the coprecipitations was interesting and led to a lot of questions regarding how these particles might affect the material's properties once the wire was made. Figure 7 shows six different samples of $\mathrm{PdTb}\left(\mathrm{C}_{2} \mathrm{O}_{4}\right)_{\mathrm{X}}$. Particle size was manually measured using ImageJ. Particle size varied between 3.6-0.4 microns with the $\mathrm{K}_{2} \mathrm{PdCl}_{4}$ starting material having the smallest particles (too small to accurately measure) and $\left(\mathrm{NH}_{3}\right)_{4} \mathrm{Pd}\left(\mathrm{NO}_{3}\right)_{2}$ from Sigma Aldrich having the largest. One interesting difference was seen in the STREM sample, where many particles were not spheres and instead come to a point (irregular in shape). EDS on these samples showed all Pd except for one sample where half the Pd was added also showed $\mathrm{Tb}$ 

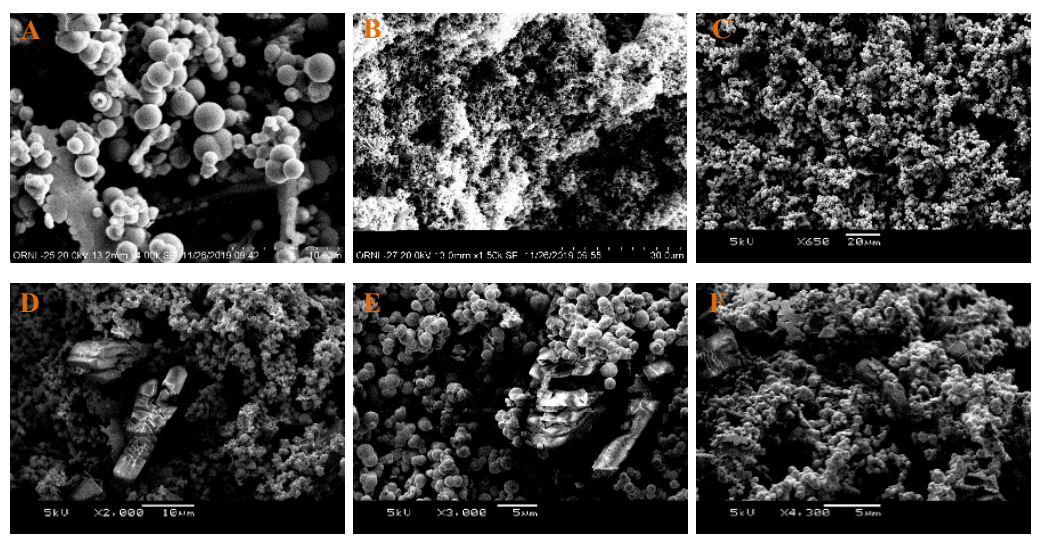

Figure 7. Scanning electron microscope (SEM) images of six different samples where $A$ is sample 9, B is sample 2, $C$ is sample 4, $D$ is sample $6, E$ is sample 5 , and $F$ is sample 1.

Once the powder was pressed into pellets, they were once again examined by SEM/EDS. Figure 8 shows SEM images of a pressed pellet. The surface of the pellet is very smooth, where steric acid that was left over and streaked down the pellet can be seen. The presence of carbon was also observed by EDS.
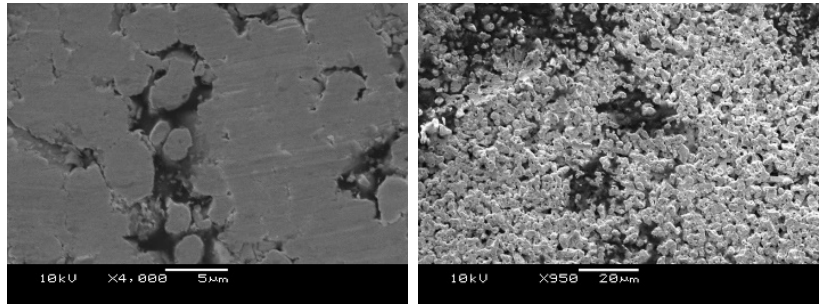

Figure 8. Scanning electron microscope (SEM) images of a pressed pellet:(left) view of the side and (right) view from the top.

The wires were imaged intermittently as they were rolled and annealed to see if there were any differences that could be seen at the surface. This rolling is a common practice among jewelers called cold rolling. Because Pd is a very ductile metal, much like silver, Pd can be cold rolled and shaped relatively easily. Most of the literature on Pd metal working says to anneal it frequently at temperatures between 800 and $1000^{\circ} \mathrm{C}$ under an inert gas or hydrogen [3-4]. It has been frequently pointed out that a Pd layer can oxidize when annealed in air, also known as palladium blushing, which can cause flaking and cracking in the wire. Figure 9 shows three stages of a wire being rolled out. The first roll, after annealing, and the second roll. Some differences before and after annealing can be seen.
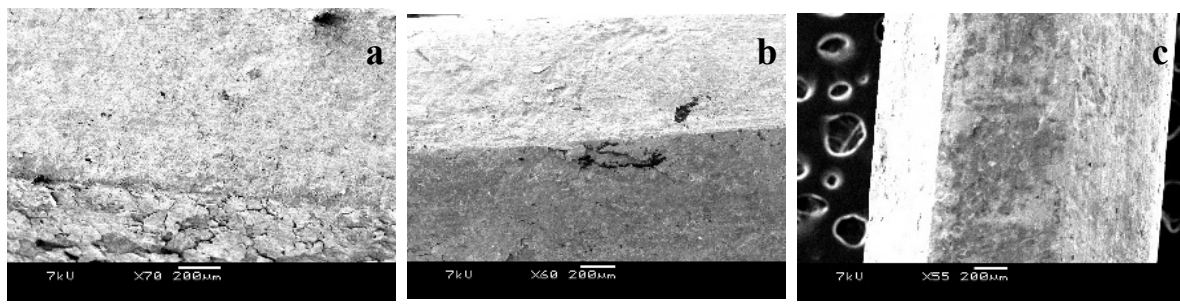

Figure 9. Scanning Electron Microscope (SEM) images of a wire being rolled out in three different stages. 
The wire in Figure 9a shows a considerable amount of cracking or flaking, whereas blistering appears to be more of an issue in the wire in Figure 9b. Figure 9c shows a wire after it has been annealed in Ar after rolling. Here you can see though there is still minor cracking, its left in a much better condition than seen in Figure 9a and b. It should also be pointed out that the EDS shows Pd, C, iron (Fe) for all samples, meaning that $\mathrm{Fe}$ has been picked up from the well-used and rust-laden rolling mill. Figure 10 shows all the wires produced on the rolling mill. Here you can see there are large differences in how much these wires are cracking and flaking. Since they have been heat treated and rolled in the same way the current explanation for this lends to differences in the grain structure and particle sizes between the samples.

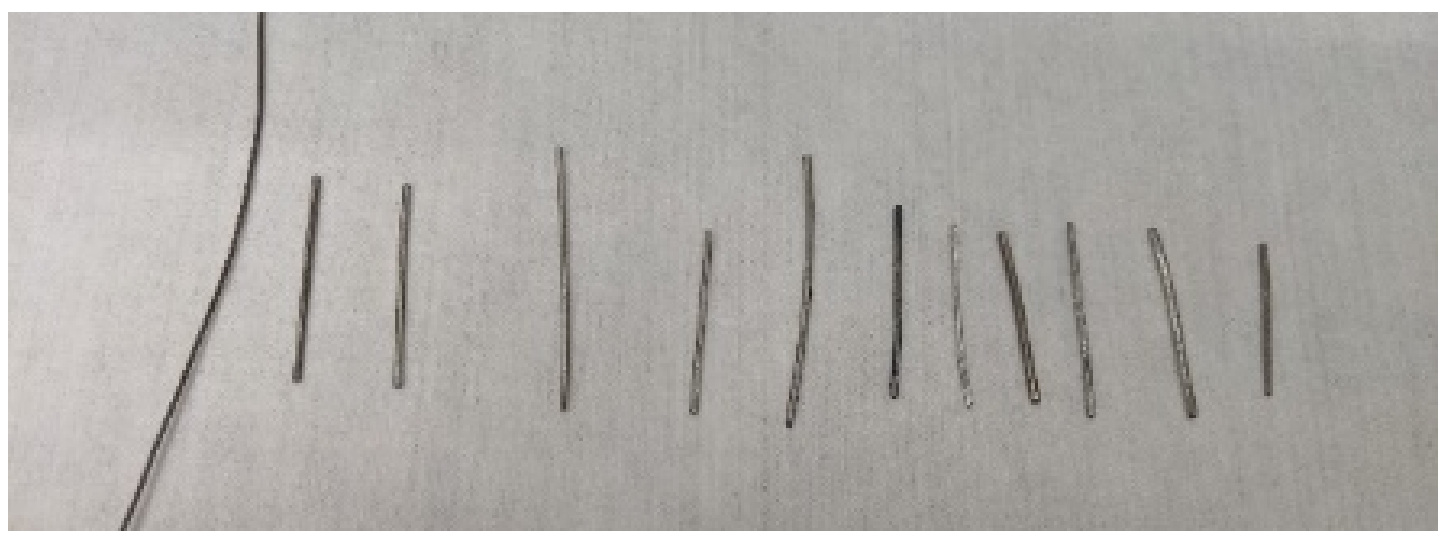

Figure 10. Several wires that have been rolled out for this study.

\section{DISCUSSION AND RESULTS}

This study aimed to understand the fundamental chemistry of Cf-252 wire fabrication. Using $\mathrm{Tb}$ as a surrogate material for $\mathrm{Cf}$, we have begun to understand some of the underlying complications of this process. In total six variables were tested to better understand the chemistry of the wire fabrication process. The variables were (1) oxalic acid concentration, (2) Tb concentration, (3) nitric acid concentration, (4) volumes, (5) $\alpha$-hydroxyiso-butyrate (AHIB) concentration, and (6) differing Pd suppliers. In short, this study illustrates the narrow processing conditions required to produce a viable product thus improving $\mathrm{Cf}$ wire fabrication.

One known contaminant found in this process is AHIB (Figure 11). AHIB comes from a purification step earlier in the process in which $\mathrm{Cf}$ is separated from $\mathrm{Cm}$. Because AHIB has a good affinity for binding actinides, it is possible that it competes for binding with oxalic acid during the first precipitation, which could result in lower yields. To avoid this, the feed solution is typically boiled in $8 \mathrm{M}$ nitric acid to break down the AHIB ligand. However, boiling nitric acid adds additional time to this process and has led to oxidation of metals inside the hot cells. Because of this reason, this step is usually skipped.<smiles>CC(C)(O)C(=O)O</smiles>

Figure 11. A structural drawing of the AHIB ligand.

To test how AHIB affects oxalate precipitation, several concentrations of AHIB were added to Tb prior to oxalate precipitation. The $\mathrm{pH}$ was adjusted to $\sim 1$, and then oxalate was added. ICP-OES data suggests up to a $40 \%$ loss of $\mathrm{Tb}$ compared with precipitations without AHIB present (Table 2). Due to the relatively large loss that was observed, it appears to be very important that the AHIB ligand be removed prior to preforming oxalate precipitations. 
Table 2. Effect on Tb concentration when the AHIB concentration is varied.

\begin{tabular}{|c|c|c|}
\hline Starting amount of Tb (mg) & AHIB (pH 4.8) & Tb left in supernatant (mg) \\
\hline 15.4 & $0.05 \mathrm{M}$ & 0.16 \\
\hline 15.2 & $0.10 \mathrm{M}$ & 1.14 \\
\hline 15.3 & $0.50 \mathrm{M}$ & 4.74 \\
\hline
\end{tabular}

Concentrations of $\mathrm{Tb}$, oxalic acid, and volume of the total solution were also evaluated for $\mathrm{Tb}$ loss in the oxalate precipitation. Our findings showed that all these variables do affect the yield of the oxalate precipitation, even if it is only minor. In general, larger volumes and higher concentrations of $\mathrm{Tb}$ or oxalate lead to larger $\mathrm{Tb}$ loses in solution (Tables 3-5). All these outcomes can be rationalized simply. First, having higher volumes dilutes both the $\mathrm{Tb}$ and oxalic acid, and if the time and temperature of the reaction are kept consistent, this could lead to lower yields. Second, high concentrations of $\mathrm{Tb}$ in solution under the same reaction conditions as a lower concentration of Tb will most likely shift the reaction equilibrium, leading to more $\mathrm{Tb}$ being left in solution. Similarly, the equilibrium can also shift when a very large excess of oxalic acid is added, making the free $\mathrm{Tb}$ more likely to be in solution.

Table 3. Effect on Tb concentration when the volume of nitric acid is varied.

\begin{tabular}{|c|c|c|}
\hline Starting amount of Tb (mg) & Nitric Acid (0.1 M) & 4Tb left in supernatant (mg) \\
\hline 15.0 & $20 \mathrm{~mL}$ & 0.034 \\
\hline 15.2 & $30 \mathrm{~mL}$ & 0.033 \\
\hline 15.4 & $40 \mathrm{~mL}$ & 0.051 \\
\hline 15.3 & $45 \mathrm{~mL}$ & 0.046 \\
\hline
\end{tabular}

Table 4. Effect of varying the initial concentration of $\mathrm{Tb}$ on the concentration of $\mathrm{Tb}$ left in solution.

\begin{tabular}{|c|c|}
\hline Starting amount of Tb (mg) & Tb left in supernatant (mg) \\
\hline 5.10 & 0.018 \\
\hline 10.17 & 0.032 \\
\hline 15.30 & 0.048 \\
\hline 30.17 & 1.802 \\
\hline
\end{tabular}

Table 5. Residual Tb in supernatant while varying concentrations of oxalic acid.

\begin{tabular}{|c|c|c|}
\hline Starting amount of Tb (mg) & Oxalic Acid $(\mathbf{M})$ & Tb left in supernatant (mg) \\
\hline 15.2 & 0.05 & 0.022 \\
\hline 15.4 & 0.10 & 0.023 \\
\hline 15.1 & 0.25 & 0.026 \\
\hline 15.4 & 0.50 & 0.032 \\
\hline 15.0 & 0.75 & 0.030 \\
\hline
\end{tabular}

Another important factor in both the oxalate and $\mathrm{Pd}$ precipitation is the $\mathrm{pH}$ of the solution. Due to the highly radioactive nature of $\mathrm{Cf}$, most of the $\mathrm{pH}$ adjustments are calculated instead of being accurately titrated or measured, which can leave large margins of error between the calculated and the actual $\mathrm{pH}$ of the solution. It has been shown that having a low $\mathrm{pH}$ when performing an oxalate precipitation will negatively affect the yield [5] and, in turn, will directly inhibit the formation of $\mathrm{Tb}\left(\mathrm{H}_{2} \mathrm{C}_{2} \mathrm{O}_{4}\right)$. In fact, we did see a trend, indicating more $\mathrm{Tb}$ is left in solution as the acid concentration increases; but, these values 
were much lower than those observed for other conditions, such as AHIB (Table 6). Here we only observed a $1 \%$ loss of $\mathrm{Tb}$ from concentrations ranging from $0.01 \mathrm{M}-0.03 \mathrm{M}$. Another factor in coprecipitation is the ability to precipitate out Pd metal. It has been reported in the literature that electroless plating of $\mathrm{Pd}$ in low $\mathrm{pH}$ results in less Pd being reduced to metal [5]. Another factor in plating is the presence of oxalic acid. A study by Steinmetz et al. showed that oxalate will also inhibit the reduction of Pd by being oxidized by hydrazine instead. One more possible issue is the formation of a Pdoxalate complex in solution. To avoid such issues, a large excess of hydrazine is added prior to adding any Pd to ensure that all the excess oxalate is oxidized and there is enough hydrazine left over to reduce $\mathrm{Pd}^{2+}$ to $\mathrm{Pd}^{0}$. Upon adding Pd to the hydrazine hydrate solution, Pd black is formed, and in some cases, mirroring (the formation of a thin palladium metal layer) occurs on the sides of the reaction vessel. It is a common misconception that the metallic Pd (the mirror) is the product of interest; instead, the Pd black is our primary and desired product.

Table 6. Residual $\mathrm{Tb}$ left in supernatant after varying the concentration of nitric acid.

\begin{tabular}{|c|c|c|}
\hline Starting amount of Tb (mg) & Nitric Acid (M) & Tb left in supernatant (mg) \\
\hline 15.2 & 0.01 & 0.022 \\
\hline 15.3 & 0.05 & 0.033 \\
\hline 15.5 & 0.10 & 0.036 \\
\hline 14.7 & 0.20 & 0.134 \\
\hline 15.2 & 0.30 & 0.152 \\
\hline
\end{tabular}

The Pd black product ranges in color from light grey to black, depending on the source of Pd used. Though this color change is noticeable, we currently do not have an explanation for what causes this effect. Particle size also changes for these reactions but does not seem to correlate directly to color. Scanning electron microscopy (SEM) was used to image all solids, and ImageJ was used to measure particle size. Particle size ranged from 3.6-0.4 microns, though some samples had particles that were too small to measure on this instrument. In some cases, particle shape was also different. For example, using Pd from Strem Chemicals, Inc. as a starting material yielded particles that are not perfect spheres, rather more oblong and jagged, (Figure 7).

After particle formation, drying followed by calcining the solid can also change the appearance of the powder. In most cases, after calcination the solid is fused together in one solid puck. To better understand the chemistry that is occurring during calcination, several reactions were run with and without calcination. Testing was conducted using two samples of each of the following: (1) No $\mathrm{Tb}$ added (only $\mathrm{Pd}$ ) (2) $\mathrm{Tb}_{4} \mathrm{O}_{7}$ as $\mathrm{Tb}$ source (3) $\mathrm{Tb}\left(\mathrm{NO}_{3}\right)_{3}$ as $\mathrm{Tb}$ source. One sample of each was dried followed by calcination and the other was dried but not calcined. All of the samples were then pressed into pellets and melted using the same methods. Upon examining the samples from (1) when the solid was calcined with no $\mathrm{Tb}$, more oxidation to the Pd was noticeable. Figure 12 shows solid after it had been calcined. When the pellet was pressed, it broke up into pieces and did not stay in a pellet form. However, for the pellet that was prepared without calcination, no oxidation to the Pd was observed (Figure 13). The pellet broke off at the end but stayed mostly intact with a metallic luster. Pellets that were prepared using (2) and (3) did not show any signs of Pd oxidation. All pellets were successfully pressed and stayed fully intact. All but three pellets were melted using a combination of $\mathrm{He} / \mathrm{H}_{2}(4 \%)$ and $\mathrm{Ar}$. 
In all, 21 wires were fabricated using slight variations of the original Cf-252 method and are shown in Figure 10. The visual differences between the wires should be noted. Some exhibited much more cracking, splintering, and blistering than others. From this we determined that more cracking occurred when less than 0.7 gram of Pd was used. More cracking/splintering was also observed when annealing was inconsistent or done in air instead of Ar. Other factors such as the manufacturer of Pd could be playing a role in this as well, but with so many variables, it is hard to place blame on one factor.

Understanding what complexes are forming during this procedure is

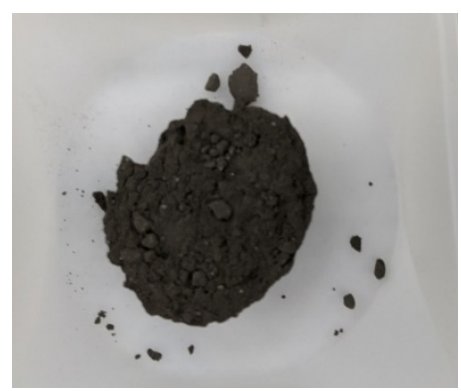

Figure 13. Pd black product without calcination. not trivial. The common assumption is the formation of Pd black metal and the oxide of the lanthanide used $\left(\operatorname{Ln}_{2} \mathrm{O}_{3}\right)$. However, the formation of $\operatorname{LnPd}_{x}(x=2,3,4$, etc. $)$ complexes are possible in both the reduction and melting steps performed during the procedure. In fact, there are reports of $\mathrm{LnPd}_{3}$ complexes being formed by melting $\mathrm{Ln}$ oxides with $\mathrm{Pd}$ metal in $\mathrm{H}_{2}$ at elevated temperatures [6]. To further explore if other coordination complexes were being formed, we tried to adjust ratios of $\mathrm{Tb}: \mathrm{Pd}$ to see if $\mathrm{TbPd}_{3}$ or even $\mathrm{TbPd}_{5}$ formed. $\mathrm{The}^{\mathrm{TbPd}} \mathrm{P}_{3}$ and $\mathrm{TbPd}_{5}$ were coprecipitated, dried, and calcined per the procedure. Additional studies such as X-ray photoelectron spectroscopy (XPS) measurements are still ongoing. In addition, $\mathrm{pXRD}$ was taken of $\mathrm{TbPd}_{3}$ along with several other samples from this study. Figure 6 shows the patterns overlaid. In the $\mathrm{TbPd}_{3}$, the presence of an intermetallic compound, TbPd, is very pronounced [7]. This is present in all the Tb containing samples but tends to get drowned out by the large excess of Pd present. Another interesting aspect observed was when Fe was present alongside the $\mathrm{Tb}$, the TbPd intermetallic was also more pronounced. We believe this can be attributed to the formation of FePd, which crystalizes in the same space group (Pm $\overline{3} \mathrm{~m})$ as $\mathrm{TbPd}$.

Based on these results, we make the following recommendations using these methods.

1. It is very important that AHIB be removed prior to starting oxalate precipitation. Not doing so will result in substantial product losses.

2. Both volume and acid concentrations should be kept low. These variables will affect both the oxalate precipitation and the Pd precipitation, resulting in lower yields.

3. When selecting a palladium starting material, the most important aspect is that it be soluble in $0.1 \mathrm{M}$ nitric acid.

4. Calcination does not seem to be necessary for wire fabrication, as the same result can be obtained from materials whether or not they have been through the calcination process.

5. It is critical that Ar be used when heating Pd metal, especially during annealing operations. Without Ar, the Pd will start to oxidize and product losses can be expected. It is also very important to anneal frequently to avoid overworking the wire, which can severely weaken it.

Future studies will shift focus from Tb to Cf by using Cf-249 as a surrogate for Cf-252. Cf-249 is the preferred Cf isotope because its neutron emission rate is much lower than Cf-252. This will facilitate the ability to perform a variety of physical and chemical measurements. Additionally, we plan to study how neutrons affect the material properties of Pd metal over time. The combination of these studies should close the gap in our understanding of the Cf-252 wire fabrication process. 


\section{ACKNOWLEDGMENTS}

This work is supported by the US Department of Energy Isotope Program, managed by the Office of Science for Isotope R\&D and Production. ORNL is managed by UT-Battelle, LLC, for the US Department of Energy under contract DE-AC05-00OR22725. The authors would also like to acknowledge Edward Smith, C. Scott White, Daniel Bettinger, and John Courtney II for their advice and support throughout this project.

\section{REFERENCES}

1. Mosley, W. C., P. K. Smith, and P. E. McBeath. 1975. "Neutron Sources of Palladium ${ }^{252}$ Cf Oxide Cermet Wire. Applications of Californium-252." In Proceedings of the American Nuclear Society National Topical Meeting, Austin, Texas, September 11-13, 1972.

2. Fuschillo, N., and M. L. Gimpl. 1970. "Electrical and Tensile Properties of Cu-ThO2, Au-ThO2, PtThO2, and Au-AI2O3, Pt-A1203 Alloys.” J. Mater. Science 5 (1970): 1078.

3. “Working Palladium." https://media1.riogrande.com/Content/Working-Palladium-IS.pdf, visited August 18, 2020.

4. Rayktsaum, G. 2016. “Annealing of Precious Metals.” In Heat Treating of Nonferrous Alloys, Vol. 4E, edited by G. E. Totten, 660-663. ASM International.

5. Steinmetz, P., S. Alperine, A. Friant-Costantini, and P. Josso. 1990. "Electroless Deposition of Pure Nickel, Palladium, and Platinum.” Surface and Coatings Technology 43/44 (1990): 500-510.

6. Erdmann, B., and C. Keller. 1973. "Actinide(Lanthanide)-Noble Metal Alloy Phases, Preparation and Properties.” Journal of Solid State Chemistry 7 (1973): 40-48.

7. Palenzona, A. and S. Cirafici. 1975. "Thermodynamic and crystallographic properties of REPd intermetallic compounds." Thermochimica Acta 12 (1975): 267-275. 


\section{APPENDIX A. SUPPLEMENTARY INFORMATION}

General Considerations. The terbium(III) nitrate hexahydrate (99.9\%, Sigma Aldrich), terbium(II,IV) oxide (99.9\% trace metal basis, Sigma Aldrich), samarium(III) nitrate hexahydrate $(99.9 \%$, Sigma Aldrich), tetraamminepalladium(II) dinitrate (99.9\% trace metal basis, BeanTown Chemical), tetraamminepalladium(II) dinitrate (99.9\% trace metal basis, STREM), tetraamminepalladium(II) dinitrate (99.9\% trace metal basis, Sigma Aldrich), potassium tetrachloropalladate(II) $(99.99 \%$ trace metal basis, Sigma Aldrich), palladium wire (99.99\%, Refining Systems Inc.), hydrazine monohydrate (98\%, Sigma Aldrich), oxalic acid (99.9\%, Sigma Aldrich), acetone (99\%, Sigma Aldrich), nitric acid $\left(\mathrm{HNO}_{3}\right.$; Fisher), and stearic acid (Sigma Aldrich) were obtained commercially and used as received. All water used in these experiments was deionized and passed through a carbon filter system in Bldg. 7930.

Oxalate concentration: Added to a Pyrex tube was $\mathrm{Tb}\left(\mathrm{NO}_{3}\right)_{3}-6\left(\mathrm{H}_{2} \mathrm{O}\right)(43 \mathrm{mg})$ and nitric acid $(0.1 \mathrm{M}, 45$ $\mathrm{mL})$. The tube was heated to $60^{\circ} \mathrm{C}$ while occasionally stirring. Once at temperature, $15 \mathrm{~mL}$ of varying oxalic acid concentrations $(0.05 \mathrm{M}, 0.1 \mathrm{M}, 0.25 \mathrm{M}, 0.5 \mathrm{M}$ and $0.75 \mathrm{M})$ were added. The reaction sat for 1 hour at temperature to ensure the reaction was complete. The solutions were then filtered, discarding the solid product. The solutions were then boiled down to a residue and brought up in nitric acid ( $0.44 \mathrm{M}$, $5 \mathrm{~mL}$ ) for ICP-OES analysis.

AHIB concentration: Added to a Pyrex tube was $\mathrm{Tb}\left(\mathrm{NO}_{3}\right)_{3}-6\left(\mathrm{H}_{2} \mathrm{O}\right)(43 \mathrm{mg})$ and $30 \mathrm{~mL}$ of differing concentrations of AHIB $(0.05 \mathrm{M}, 0.1 \mathrm{M}, 0.5 \mathrm{M}, 0.75 \mathrm{M})$ at $\mathrm{pH} 4.8$. The $\mathrm{pH}$ was then adjusted to 1 using a $\mathrm{pH}$ meter and nitric acid. The tube was heated to $60^{\circ} \mathrm{C}$ while occasionally stirring. Once at temperature, oxalic acid $(1 \mathrm{M}, 3 \mathrm{~mL})$ was added. The reaction sat for 1 hour at temperature to ensure the reaction was complete. The solutions were then filtered, discarding the solid product. The solutions were then boiled down to a residue and brought up in nitric acid $(0.44 \mathrm{M}, 5 \mathrm{~mL})$ for ICP-OES analysis.

Nitric acid concentration: Added to a Pyrex tube was $\mathrm{Tb}\left(\mathrm{NO}_{3}\right)_{3}-6\left(\mathrm{H}_{2} \mathrm{O}\right)(43 \mathrm{mg})$ and varying concentrations of nitric acid $(0.01 \mathrm{M}, 0.05 \mathrm{M}, 0.1 \mathrm{M}, 0.2 \mathrm{M}, 0.3 \mathrm{M}: 45 \mathrm{~mL})$. The tube was heated to $60^{\circ} \mathrm{C}$ while occasionally stirring. Once at temperature, oxalic acid $(1 \mathrm{M}, 3 \mathrm{~mL})$ was added. The reaction sat for 1 hour at temperature to ensure the reaction was complete. The solutions were then filtered, discarding the solid product. The solutions were then boiled down to a residue and brought up in nitric acid ( $0.44 \mathrm{M}$, $5 \mathrm{~mL}$ ) for ICP-OES analysis.

Tb concentration: Added to a Pyrex tube was $\mathrm{Tb}\left(\mathrm{NO}_{3}\right)_{3}-6\left(\mathrm{H}_{2} \mathrm{O}\right)(9 \mathrm{mg}, 14.5 \mathrm{mg}, 29 \mathrm{mg}, 43 \mathrm{mg}, 86 \mathrm{mg})$ and nitric acid $(0.01 \mathrm{M}, 45 \mathrm{~mL})$. The tube was heated to $60^{\circ} \mathrm{C}$ while occasionally stirring. Once at temperature, oxalic acid $(1 \mathrm{M}, 3 \mathrm{~mL})$ was added. The reaction sat for 1 hour at temperature to ensure the reaction was complete. The solutions were then filtered, discarding the solid product. The solutions were then boiled down to a residue and brought up in nitric acid $(0.44 \mathrm{M}, 5 \mathrm{~mL})$ for ICP-OES analysis.

Volume variations: Added to a Pyrex tube was $\mathrm{Tb}\left(\mathrm{NO}_{3}\right)_{3}-6\left(\mathrm{H}_{2} \mathrm{O}\right)(43 \mathrm{mg})$ and varying volumes of $0.1 \mathrm{M}$ nitric acid $(20 \mathrm{~mL}, 30 \mathrm{~mL}, 40 \mathrm{~mL}, 45 \mathrm{~mL})$. The tube was heated to $60^{\circ} \mathrm{C}$ while occasionally stirring. Once at temperature, oxalic acid $(1 \mathrm{M}, 3 \mathrm{~mL})$ was added. The reaction sat for 1 hour at temperature to ensure the reaction was complete. The solutions were then filtered, discarding the solid product. The solutions were then boiled down to a residue and brought up in nitric acid $(0.44 \mathrm{M}, 5 \mathrm{~mL})$ for ICP-OES analysis.

Hydrazine concentration: Added to a Pyrex tube was $\mathrm{Tb}\left(\mathrm{NO}_{3}\right)_{3}-6\left(\mathrm{H}_{2} \mathrm{O}\right)(43 \mathrm{mg})$ and $0.1 \mathrm{M}$ nitric acid $(45 \mathrm{~mL})$. The tube was heated to $60^{\circ} \mathrm{C}$ while occasionally stirring. Once at temperature, oxalic acid ( $1 \mathrm{M}$, $3 \mathrm{~mL}$ ) was added. The reaction sat for 1 hour at temperature to ensure the reaction was complete. Then hydrazine hydrate was added in varying volumes $(1 \mathrm{~mL}, 2 \mathrm{~mL}, 3 \mathrm{~mL})$ to the reactions followed by the 
slow addition of $\left(\mathrm{NH}_{3}\right)_{4} \mathrm{Pd}\left(\mathrm{NO}_{3}\right)_{2}(15 \mathrm{~mL}$, Beantown). After 1 hour the heat was turned off and the reactions sat overnight. Once settled the supernatant was pipetted off and saved for ICP-OES analysis.

1_SKS_12: Added to a quartz tube were $\mathrm{Tb}\left(\mathrm{NO}_{3}\right)_{3}(0.03 \mathrm{M}, 15 \mathrm{~mL})$ and $\mathrm{HNO}_{3}(0.1 \mathrm{M}, 45 \mathrm{~mL})$. The quartz tube was heated to $60^{\circ} \mathrm{C}$ while a constant stream of Ar was bubbling through the solution. Once the quartz tube reached $60^{\circ} \mathrm{C}$ the oxalic acid solution $(0.1 \mathrm{M}, 15 \mathrm{~mL})$ was added slowly to the quartz tube. The solution turned cloudy within seconds and a precipitate started to form. The reaction was left to react for 1 hour while continuing to heat and bubble Ar. The tube was then removed from the heat, and the hydrazine hydrate $(3 \mathrm{~mL})$ was added. The tube was returned to the bath, and the $\left(\mathrm{NH}_{3}\right)_{4} \mathrm{Pd}\left(\mathrm{NO}_{3}\right)_{2}(7 \mathrm{~mL}$, Beantown) solution was added very slowly to avoid excess bubbling (known as foaming). Upon adding $\mathrm{Pd}$, the solution turned black and started to slowly bubble $\left(\mathrm{H}_{2}\right.$ gas). After $5 \mathrm{~mL}$ a $\mathrm{Pd}^{0}$ mirror coated the quartz tube. After 30 minutes the coating fell off the tube. Once the Ar gas was removed, the solids floated to the bottom. The reaction was left to sit overnight. The supernatant was carefully pipetted off to avoid any product loss. The solid was transferred to a glass vial and washed with water $(100 \mathrm{~mL})$ three times. The sample was air dried before an aliquot for pXRD and SEM was taken. The sample was then placed back into the quartz tube and was heated to $100^{\circ} \mathrm{C}$ (at $5^{\circ} \mathrm{C} / \mathrm{min}$ ) for 2 hours, and then it ramped to $200^{\circ} \mathrm{C}\left(15^{\circ} \mathrm{C} / \mathrm{min}\right)$ where it remained for 8 hours under Ar before being shut off. The gas was then switched to $\mathrm{He} / \mathrm{H}_{2}(4 \%)$, and the furnace was ramped up to $700^{\circ} \mathrm{C}$ at $15^{\circ} \mathrm{C} / \mathrm{min}$ where it remained for 30 min before being shut off. The sample was removed from the quartz tube and placed into a vial for storage.

2_SKS_K2PdCl2: Added to a quartz tube were $\mathrm{Tb}\left(\mathrm{NO}_{3}\right)_{3}(0.03 \mathrm{M}, 15 \mathrm{~mL})$ and $\mathrm{HNO}_{3}(0.1 \mathrm{M}, 45 \mathrm{~mL})$. The quartz tube was heated to $60^{\circ} \mathrm{C}$ while a constant stream of Ar was bubbling through the solution. Once the quartz tube reached $60^{\circ} \mathrm{C}$, the oxalic acid solution $(0.1 \mathrm{M}, 15 \mathrm{~mL})$ was added slowly to the quartz tube. The solution turned cloudy within seconds and a precipitate started to form. The reaction was left to react for 1 hour while continuing to heat and bubble Ar. The tube was then removed from heat, and the hydrazine hydrate $(3 \mathrm{~mL})$ was added. The tube was returned to the bath and $\mathrm{K}_{2} \mathrm{PdCl}_{2}(655.8 \mathrm{mg})$ dissolved in $\mathrm{HNO}_{3}(5 \mathrm{~mL} 0.1 \mathrm{M})$ was added very slowly to avoid excess bubbling (known as foaming). Upon adding Pd the solution turned black and started to slowly bubble $\left(\mathrm{H}_{2}\right.$ gas). After $5 \mathrm{~mL}$ a Pd ${ }^{0}$ mirror coated the quartz tube. After 30 minutes the coating fell off the tube. Once the Ar gas was removed, the solids floated to the bottom. The reaction was left to sit overnight. The supernatant was carefully pipetted off to avoid any product loss. The solid was transferred to a glass vial and washed with water $(100 \mathrm{~mL})$ three times. The sample was air dried before an aliquot for pXRD and SEM was taken. The sample was then placed back into the quartz tube and was heated to $100^{\circ} \mathrm{C}$ (at $5^{\circ} \mathrm{C} / \mathrm{min}$ ) for 2 hours, and then it was ramped to $200^{\circ} \mathrm{C}\left(15^{\circ} \mathrm{C} / \mathrm{min}\right)$ where it remained for 8 hours under Ar before being shut off. The gas was then switched to $\mathrm{He} / \mathrm{H}_{2}(4 \%)$, and the furnace was ramped up to $700^{\circ} \mathrm{C}$ at $15^{\circ} \mathrm{C} / \mathrm{min}$ where it remained for 30 min before being shut off. The sample was removed from the quartz tube and placed into a vial for storage.

3_SKS_Ox: Added to a quartz tube were $\mathrm{Tb}_{4} \mathrm{O}_{7}(12.9 \mathrm{mg})$ and $\mathrm{HNO}_{3}(0.1 \mathrm{M}, 45 \mathrm{~mL})$. The quartz tube was heated to $60^{\circ} \mathrm{C}$ while a constant stream of Ar was bubbling through the solution. Once the quartz tube reached $60^{\circ} \mathrm{C}$, the oxalic acid solution $(0.1 \mathrm{M}, 15 \mathrm{~mL})$ was added slowly to the quartz tube. The solution turned cloudy within seconds and a precipitate started to form. The reaction was left to react for 1 hour while continuing to heat and bubble Ar. The tube was then removed from heat, and the hydrazine hydrate $(3 \mathrm{~mL})$ was added. The tube was returned to the bath, and the $\left(\mathrm{NH}_{3}\right)_{4} \mathrm{Pd}\left(\mathrm{NO}_{3}\right)_{2}(12 \mathrm{~mL}$, Beantown $)$ solution was added very slowly to avoid excess bubbling (known as foaming). Upon adding Pd the solution turned black and started to slowly bubble $\left(\mathrm{H}_{2}\right.$ gas). Once the Ar gas was removed, the solids floated to the bottom. The reaction was left to sit overnight. The supernatant was carefully pipetted off to avoid any product loss. The solid was transferred to a glass vial and washed with water $(100 \mathrm{~mL})$ three times. The sample was air dried before an aliquot for pXRD and SEM was taken. The sample was then placed back into the quartz tube and was heated to $100^{\circ} \mathrm{C}$ (at $5^{\circ} \mathrm{C} / \mathrm{min}$ ) for 2 hours, and then it was 
ramped to $200^{\circ} \mathrm{C}\left(15^{\circ} \mathrm{C} / \mathrm{min}\right)$ and where it remained for 8 hours under Ar before shutting off. The gas was then switched to $\mathrm{He} / \mathrm{H}_{2}(4 \%)$, and the furnace was ramped up to $700^{\circ} \mathrm{C}$ at $15^{\circ} \mathrm{C} / \mathrm{min}$ where it remained for $30 \mathrm{~min}$ before being shut off. The sample was removed from the quartz tube and placed into a vial for storage.

4_SKS_sigma: Added to a quartz tube were $\mathrm{Tb}\left(\mathrm{NO}_{3}\right)_{3}(0.03 \mathrm{M}, 15 \mathrm{~mL})$ and $\mathrm{HNO}_{3}(0.1 \mathrm{M}, 45 \mathrm{~mL})$. The quartz tube was heated to $60^{\circ} \mathrm{C}$ while a constant stream of Ar was bubbling through the solution. Once the quartz tube reached $60^{\circ} \mathrm{C}$, the oxalic acid solution $(0.1 \mathrm{M}, 15 \mathrm{~mL})$ was added slowly to the quartz tube. The solution turned cloudy within seconds and a precipitate started to form. The reaction was left to react for 1 hour while continuing to heat and bubble Ar. The tube was then removed from heat, and the hydrazine hydrate $(3 \mathrm{~mL})$ was added. The tube was returned to the bath, and the $\left(\mathrm{NH}_{3}\right)_{4} \mathrm{Pd}\left(\mathrm{NO}_{3}\right)_{2}(20 \mathrm{~mL}$, Sigma Aldrich) solution was added very slowly to avoid excess bubbling (known as foaming). Upon adding Pd the solution turned black and started to slowly bubble $\left(\mathrm{H}_{2}\right.$ gas $)$. After $5 \mathrm{~mL}$ a $\mathrm{Pd}^{0}$ mirror coated the quartz tube. After 30 minutes the coating fell off the tube. Once the Ar gas was removed, the solids floated to the bottom. The reaction was left to sit overnight. The supernatant was carefully pipetted off to avoid any product loss. The solid was transferred to a glass vial and washed with water $(100 \mathrm{~mL})$ three times. The sample was air dried before an aliquot for pXRD and SEM was taken. The sample was then placed back into the quartz tube and was heated to $100^{\circ} \mathrm{C}$ (at $5^{\circ} \mathrm{C} / \mathrm{min}$ ) for 2 hours, and then it ramped to $200^{\circ} \mathrm{C}\left(15^{\circ} \mathrm{C} / \mathrm{min}\right)$ where it remained for 8 hours under Ar before being shut off. The gas was then switched to $\mathrm{He} / \mathrm{H}_{2}(4 \%)$, and the furnace was ramped up to $700^{\circ} \mathrm{C}$ at $15^{\circ} \mathrm{C} / \mathrm{min}$ where it remained for $30 \mathrm{~min}$ before being shut off. The sample was removed from the quartz tube and placed into a vial for storage.

5_SKS_Ed1: Added to a quartz tube were $\mathrm{Tb}\left(\mathrm{NO}_{3}\right)_{3}(0.03 \mathrm{M}, 15 \mathrm{~mL})$ and $\mathrm{HNO}_{3}(0.1 \mathrm{M}, 45 \mathrm{~mL})$. The quartz tube was heated to $60^{\circ} \mathrm{C}$ while a constant stream of Ar was bubbling through the solution. Once the quartz tube reached $60^{\circ} \mathrm{C}$, the oxalic acid solution $(0.1 \mathrm{M}, 15 \mathrm{~mL})$ was added slowly to the quartz tube. The solution turned cloudy within seconds, and a precipitate started to form. The reaction was left to react for 1 hour while continuing to heat and bubble Ar. The tube was then removed from heat, and the hydrazine hydrate $(3 \mathrm{~mL})$ was added. The tube was returned to the bath, and the $\left(\mathrm{NH}_{3}\right)_{4} \mathrm{Pd}\left(\mathrm{NO}_{3}\right)_{2}(15 \mathrm{~mL}$, Beantown) solution was added very slowly to avoid excess bubbling (known as foaming). Upon adding $\mathrm{Pd}$ the solution turned black and started to slowly bubble $\left(\mathrm{H}_{2}\right.$ gas). After $5 \mathrm{~mL}$ a $\mathrm{Pd}^{0}$ mirror coated the quartz tube. After 30 minutes the coating fell off the tube. Once the Ar gas was removed, the solids floated to the bottom. The reaction was left to sit overnight. The supernatant was carefully pipetted off to avoid any product loss. The solid was transferred to a glass vial and washed with water $(100 \mathrm{~mL})$ three times. The sample was air dried before an aliquot for pXRD and SEM was taken. The sample was then placed back into the quartz tube and was heated to $100^{\circ} \mathrm{C}$ (at $5^{\circ} \mathrm{C} / \mathrm{min}$ ) for 2 hours, and then it ramped to $200^{\circ} \mathrm{C}\left(15^{\circ} \mathrm{C} / \mathrm{min}\right)$ where it remained for 8 hours under Ar before being shut off. The gas was then switched to $\mathrm{He} / \mathrm{H}_{2}(4 \%)$, and the furnace was ramped up to $700^{\circ} \mathrm{C}$ at $15^{\circ} \mathrm{C} / \mathrm{min}$ where it remained for 30 min before being shut off. The sample was removed from the quartz tube and placed into a vial for storage.

6_SKS_Strem: Added to a quartz tube were $\mathrm{Tb}\left(\mathrm{NO}_{3}\right)_{3}(0.03 \mathrm{M}, 15 \mathrm{~mL})$ and $\mathrm{HNO}_{3}(0.1 \mathrm{M}, 45 \mathrm{~mL})$. The quartz tube was heated to $60^{\circ} \mathrm{C}$ while a constant stream of Ar was bubbling through the solution. Once the quartz tube reached $60^{\circ} \mathrm{C}$, the oxalic acid solution $(0.1 \mathrm{M}, 15 \mathrm{~mL})$ was added slowly to the quartz tube. The solution turned cloudy within seconds, and a precipitate started to form. The reaction was left to react for 1 hour while continuing to heat and bubble Ar. The tube was then removed from heat, and the hydrazine hydrate $(3 \mathrm{~mL})$ was added. The tube was returned to the bath and the $\left(\mathrm{NH}_{3}\right)_{4} \mathrm{Pd}\left(\mathrm{NO}_{3}\right)_{2}(10 \mathrm{~mL}$, 0.0047 moles, STREM) solution was added very slowly to avoid excess bubbling (known as foaming). Upon adding Pd the solution turned black and started to slowly bubble $\left(\mathrm{H}_{2}\right.$ gas). After $5 \mathrm{~mL}$ a $\mathrm{Pd}^{0}$ mirror coated the quartz tube. After 30 minutes the coating fell off the tube. Once the Ar gas was removed, the solids floated to the bottom. The reaction was left to sit overnight. The supernatant was carefully pipetted 
off to avoid any product loss. The solid was transferred to a glass vial and washed with water $(100 \mathrm{~mL})$ three times. The sample was air dried before an aliquot for $\mathrm{pXRD}$ and SEM was taken. The sample was then placed back into the quartz tube and was heated to $100^{\circ} \mathrm{C}$ (at $5^{\circ} \mathrm{C} / \mathrm{min}$ ) for 2 hours, and then it ramped to $200^{\circ} \mathrm{C}\left(15^{\circ} \mathrm{C} / \mathrm{min}\right)$ where it remained for 8 hours under $\mathrm{Ar}$ before being shut off. The gas was then switched to $\mathrm{He} / \mathrm{H}_{2}(4 \%)$, and the furnace ramped up to $700^{\circ} \mathrm{C}$ at $15^{\circ} \mathrm{C} / \mathrm{min}$ where it remained for 30 min before being shut off. The sample was removed from the quartz tube and placed into a vial for storage.

7_SKS_rev: Added to a quartz tube were $\mathrm{Tb}\left(\mathrm{NO}_{3}\right)_{3}(0.03 \mathrm{M}, 15 \mathrm{~mL})$ and $\mathrm{HNO}_{3}(0.1 \mathrm{M}, 45 \mathrm{~mL})$. The quartz tube was heated to $60^{\circ} \mathrm{C}$ while a constant stream of Ar was bubbling through the solution. Once the quartz tube reached $60^{\circ} \mathrm{C}$, the oxalic acid solution $(0.1 \mathrm{M}, 15 \mathrm{~mL})$ was added slowly to the quartz tube. The solution turned cloudy within seconds, and a precipitate started to form. The reaction was left to react for 1 hour while continuing to heat and bubble Ar. Added to the tube was $\left(\mathrm{NH}_{3}\right)_{4} \mathrm{Pd}\left(\mathrm{NO}_{3}\right)_{2}(10 \mathrm{~mL}$, Sigma Aldrich) followed by a slow addition of hydrazine hydrate $(3 \mathrm{~mL})$. The tube was returned to the bath, and the $\left(\mathrm{NH}_{3}\right)_{4} \mathrm{Pd}\left(\mathrm{NO}_{3}\right)_{2}(20 \mathrm{~mL}$, Sigma Aldrich) solution was added very slowly to avoid excess bubbling (known as foaming). Upon adding Pd the solution turned black and started to slowly bubble $\left(\mathrm{H}_{2}\right.$ gas).

After $5 \mathrm{~mL}$ a $\mathrm{Pd}^{0}$ mirror coated the quartz tube. After 30 minutes the coating fell off the tube. Once the Ar gas was removed, the solids floated to the bottom. The reaction was left to sit overnight. The supernatant was carefully pipetted off to avoid any product loss. The solid was transferred to a glass vial and washed with water $(100 \mathrm{~mL})$ three times. The sample was air dried before an aliquot for $\mathrm{pXRD}$ and SEM was taken. The sample was then placed back into the quartz tube and was heated to $100^{\circ} \mathrm{C}\left(\right.$ at $\left.5^{\circ} \mathrm{C} / \mathrm{min}\right)$ for 2 hours, and then it ramped to $200^{\circ} \mathrm{C}\left(15^{\circ} \mathrm{C} / \mathrm{min}\right)$ where it remained for 8 hours under Ar before being shut off. The gas was then switched to $\mathrm{He} / \mathrm{H}_{2}(4 \%)$, and the furnace was ramped up to $700^{\circ} \mathrm{C}$ at $15^{\circ} \mathrm{C} / \mathrm{min}$ where it remained for $30 \mathrm{~min}$ before being shut off. The sample was removed from the quartz tube and placed into a vial for storage.

8_SKS_rev: Added to a quartz tube were $\mathrm{Tb}\left(\mathrm{NO}_{3}\right)_{3}(0.03 \mathrm{M}, 15 \mathrm{~mL})$ and $\mathrm{HNO}_{3}(0.1 \mathrm{M}, 45 \mathrm{~mL})$. The quartz tube was heated to $60^{\circ} \mathrm{C}$ while a constant stream of Ar was bubbling through the solution. Once the quartz tube reached $60^{\circ} \mathrm{C}$, the oxalic acid solution $(0.1 \mathrm{M}, 15 \mathrm{~mL})$ was added slowly to the quartz tube. The solution turned cloudy within seconds and a precipitate started to form. The reaction was left to react for 1 hour while continuing to heat and bubble Ar. Added to the tube was $\left(\mathrm{NH}_{3}\right)_{4} \mathrm{Pd}\left(\mathrm{NO}_{3}\right)_{2}(10 \mathrm{~mL}$, Sigma Aldrich) followed by a slow addition of hydrazine hydrate $(3 \mathrm{~mL})$. Upon adding hydrazine hydrate the solution turned brown/yellow and started to slowly bubble $\left(\mathrm{H}_{2}\right.$ gas). Once the Ar gas was removed, the solids floated to the bottom. The reaction was left to sit overnight. The supernatant was carefully pipetted off to avoid any product loss. The solid was transferred to a glass vial and washed with water (100 $\mathrm{mL})$ three times. The sample was air dried before an aliquot for pXRD and SEM was taken. The sample was then placed back into the quartz tube and was heated to $100^{\circ} \mathrm{C}$ (at $5^{\circ} \mathrm{C} / \mathrm{min}$ ) for 2 hours, and then it ramped to $200^{\circ} \mathrm{C}\left(15^{\circ} \mathrm{C} / \mathrm{min}\right)$ where it remained for 8 hours under Ar before being shut off. The gas was then switched to $\mathrm{He} / \mathrm{H}_{2}(4 \%)$, and the furnace was ramped up to $700^{\circ} \mathrm{C}$ at $15^{\circ} \mathrm{C} / \mathrm{min}$ where it remained for $30 \mathrm{~min}$ before being shut off. The sample was removed from the quartz tube and placed into a vial for storage.

10_SKS_Fe: Added to a quartz tube were $\mathrm{Tb}\left(\mathrm{NO}_{3}\right)_{3}(0.03 \mathrm{M}, 15 \mathrm{~mL}), \mathrm{Fe}\left(\mathrm{NO}_{3}\right)_{3}(20 \mathrm{mg})$, and $\mathrm{HNO}_{3}$ $(0 . \overline{\mathrm{M}}, \overline{45} \mathrm{~mL})$. The quartz tube was heated to $60^{\circ} \mathrm{C}$ while a constant stream of Ar was bubbling through the solution. Once the quartz tube reached $60^{\circ} \mathrm{C}$, the oxalic acid solution $(0.1 \mathrm{M}, 15 \mathrm{~mL})$ was added slowly to the quartz tube. The solution turned cloudy and slightly yellow within seconds, and a precipitate started to form. The reaction was left to react for 1 hour while continuing to heat and bubble Ar. Added to the tube was $\left(\mathrm{NH}_{3}\right)_{4} \mathrm{Pd}\left(\mathrm{NO}_{3}\right)_{2}(10 \mathrm{~mL}$, Sigma Aldrich) followed by a slow addition of hydrazine hydrate $(3 \mathrm{~mL})$. The tube was returned to the bath, and the $\left(\mathrm{NH}_{3}\right)_{4} \mathrm{Pd}\left(\mathrm{NO}_{3}\right)_{2}(20 \mathrm{~mL}$, Sigma Aldrich) solution was added very slowly to avoid excess bubbling (known as foaming). Upon adding Pd the solution turned black and started to slowly bubble $\left(\mathrm{H}_{2}\right.$ gas). After $5 \mathrm{~mL}$ a $\mathrm{Pd}^{0}$ mirror coated the quartz tube. After 30 
minutes the coating fell off the tube. Once the Ar gas was removed, the solids floated to the bottom. The reaction was left to sit overnight. The supernatant was carefully pipetted off to avoid any product loss. The solid was transferred to a glass vial and washed with water $(100 \mathrm{~mL})$ three times. The sample was air dried before an aliquot for $\mathrm{pXRD}$ and SEM was taken. The sample was then placed back into the quartz tube and was heated to $100^{\circ} \mathrm{C}$ (at $5^{\circ} \mathrm{C} / \mathrm{min}$ ) for 2 hours, and then it ramped to $200^{\circ} \mathrm{C}\left(15^{\circ} \mathrm{C} / \mathrm{min}\right.$ ) where it remained for 8 hours under Ar before being shut off. The gas was then switched to $\mathrm{He} / \mathrm{H}_{2}(4 \%)$, and the furnace was ramped up to $700^{\circ} \mathrm{C}$ at $15^{\circ} \mathrm{C} / \mathrm{min}$ where it remained for $30 \mathrm{~min}$ before being shut off. The sample was removed from the quartz tube and placed into a vial for storage.

11_SKS_TbPd3: Added to a quartz tube were $\mathrm{Tb}\left(\mathrm{NO}_{3}\right)_{3}(52 \mathrm{mg})$ and $\mathrm{HNO}_{3}(0.1 \mathrm{M}, 1 \mathrm{~mL})$. The quartz tube was heated to $60^{\circ} \mathrm{C}$ while a constant stream of Ar was bubbling through the solution. Once the quartz tube reached $60^{\circ} \mathrm{C}$, the oxalic acid solution $(0.1 \mathrm{M}, 15 \mathrm{~mL})$ was added slowly to the quartz tube. The solution turned cloudy within seconds, and a precipitate started to form. The reaction was left to react for 1 hour while continuing to heat and bubble Ar. The tube was then removed from heat, and the hydrazine hydrate $(1 \mathrm{~mL})$ was added. The tube was returned to the bath, and the $\left(\mathrm{NH}_{3}\right)_{4} \mathrm{Pd}\left(\mathrm{NO}_{3}\right)_{2}(800 \mu \mathrm{L}$, Beantown) solution was added very slowly to avoid excess bubbling (known as foaming). Upon adding Pd the solution turned black and started to slowly bubble $\left(\mathrm{H}_{2}\right.$ gas $)$. After $5 \mathrm{~mL}$ a $\mathrm{Pd}^{0}$ mirror coated the quartz tube. After 30 minutes the coating fell off the tube. Once the Ar gas was removed, the solids floated to the bottom. The reaction was left to sit overnight. The supernatant was carefully pipetted off to avoid any product loss. The solid was transferred to a glass vial and washed with water $(100 \mathrm{~mL})$ three times. The sample was air dried before an aliquot for pXRD and SEM was taken. The sample was then placed back into the quartz tube and was heated to $100^{\circ} \mathrm{C}$ (at $5^{\circ} \mathrm{C} / \mathrm{min}$ ) for 2 hours, and then it ramped to $200^{\circ} \mathrm{C}\left(15^{\circ} \mathrm{C} / \mathrm{min}\right)$ where it remained for 8 hours under Ar before being shut off. The gas was then switched to $\mathrm{He} / \mathrm{H}_{2}(4 \%)$, and the furnace was ramped up to $700^{\circ} \mathrm{C}$ at $15^{\circ} \mathrm{C} / \mathrm{min}$ where it remained for $30 \mathrm{~min}$ before being shut off. The sample was removed from the quartz tube and placed into a vial for storage.

12_SKS_TbPd5: Added to a quartz tube were $\mathrm{Tb}\left(\mathrm{NO}_{3}\right)_{3}(50 \mathrm{mg})$ and $\mathrm{HNO}_{3}(0.1 \mathrm{M}, 1 \mathrm{~mL})$. The quartz tube was heated to $60^{\circ} \mathrm{C}$ while a constant stream of Ar was bubbling through the solution. Once the quartz tube reached $60^{\circ} \mathrm{C}$, the oxalic acid solution $(0.1 \mathrm{M}, 15 \mathrm{~mL})$ was added slowly to the quartz tube. The solution turned cloudy within seconds, and a precipitate started to form. The reaction was left to react for 1 hour while continuing to heat and bubble Ar. The tube was then removed from heat, and the hydrazine hydrate $(2 \mathrm{~mL})$ was added. The tube was returned to the bath, and the $\left(\mathrm{NH}_{3}\right)_{4} \mathrm{Pd}\left(\mathrm{NO}_{3}\right)_{2}(1.2 \mathrm{~mL}$, Beantown) solution was added very slowly to avoid excess bubbling (known as foaming). Upon adding Pd the solution turned black and started to slowly bubble $\left(\mathrm{H}_{2}\right.$ gas $)$. After $5 \mathrm{~mL}$ a $\mathrm{Pd}^{0}$ mirror coated the quartz tube. After 30 minutes the coating fell off the tube. Once the Ar gas was removed, the solids floated to the bottom. The reaction was left to sit overnight. The supernatant was carefully pipetted off to avoid any product loss. The solid was transferred to a glass vial and washed with water $(100 \mathrm{~mL})$ three times. The sample was air dried before an aliquot for pXRD and SEM was taken. The sample was then placed back into the quartz tube and was heated to $100^{\circ} \mathrm{C}$ (at $5^{\circ} \mathrm{C} / \mathrm{min}$ ) for 2 hours, and then it ramped to $200{ }^{\circ} \mathrm{C}\left(15^{\circ} \mathrm{C} / \mathrm{min}\right)$ where it remained for 8 hours under Ar before being shut off. The gas was then switched to $\mathrm{He} / \mathrm{H}_{2}(4 \%)$, and the furnace was ramped up to $700^{\circ} \mathrm{C}$ at $15^{\circ} \mathrm{C} / \mathrm{min}$ where it remained for 30 min before being shut off. The sample was removed from the quartz tube and placed into a vial for storage.

13_SKS_Pd: Added to a quartz tube was $\mathrm{HNO}_{3}(0.1 \mathrm{M}, 45 \mathrm{~mL})$. The quartz tube was heated to $60^{\circ} \mathrm{C}$ while a constant stream of Ar was bubbling through the solution. Once the quartz tube reached $60^{\circ} \mathrm{C}$, the oxalic acid solution $(0.1 \mathrm{M}, 10 \mathrm{~mL})$ was added slowly to the quartz tube. The solution turned cloudy within seconds, and a precipitate started to form. The reaction was left to react for 1 hour while continuing to heat and bubble Ar. The tube was then removed from heat, and the hydrazine hydrate (2 $\mathrm{mL}$ ) was added. The tube was returned to the bath, and the $\left(\mathrm{NH}_{3}\right)_{4} \mathrm{Pd}\left(\mathrm{NO}_{3}\right)_{2}(15 \mathrm{~mL}$, Beantown) solution 
was added very slowly to avoid excess bubbling (known as foaming). Upon adding Pd the solution turned black and started to slowly bubble $\left(\mathrm{H}_{2}\right.$ gas). After $5 \mathrm{~mL}$ a Pd ${ }^{0}$ mirror coated the quartz tube. After 30 minutes the coating fell off the tube. Once the Ar gas was removed, the solids floated to the bottom. The reaction was left to sit overnight. The supernatant was carefully pipetted off to avoid any product loss. The solid was transferred to a glass vial and washed with water $(100 \mathrm{~mL})$ three times. The sample was air dried before an aliquot for $\mathrm{pXRD}$ and SEM was taken. The sample was then placed back into the quartz tube and was heated to $100^{\circ} \mathrm{C}$ (at $\left.5^{\circ} \mathrm{C} / \mathrm{min}\right)$ for 2 hours, and then it ramped to $200^{\circ} \mathrm{C}\left(15^{\circ} \mathrm{C} / \mathrm{min}\right.$ ) where it remained for 8 hours under Ar before being shut off. The gas was then switched to $\mathrm{He}_{\mathrm{H}} / \mathrm{H}_{2}(4 \%)$, and the furnace ramped up to $700^{\circ} \mathrm{C}$ at $15^{\circ} \mathrm{C} / \mathrm{min}$ where it remained for $30 \mathrm{~min}$ before being shut off off. The sample was removed from the quartz tube and placed into a vial for storage.

14_SKS_Ox2: Added to a quartz tube were $\mathrm{Tb}_{4} \mathrm{O}_{7}(24.7 \mathrm{mg})$ and $\mathrm{HNO}_{3}(0.1 \mathrm{M}, 45 \mathrm{~mL})$. The quartz tube was heated to $60^{\circ} \mathrm{C}$ while a constant stream of Ar was bubbling through the solution. The tube was then removed from heat, and the hydrazine hydrate $(3 \mathrm{~mL})$ was added. The tube was returned to the bath, and the $\left(\mathrm{NH}_{3}\right)_{4} \mathrm{Pd}\left(\mathrm{NO}_{3}\right)_{2}(15 \mathrm{~mL}$, Beantown) solution was added very slowly to avoid excess bubbling (known as foaming). Upon adding Pd the solution turned black and started to slowly bubble $\left(\mathrm{H}_{2}\right.$ gas). After $5 \mathrm{~mL}$ a $\mathrm{Pd}^{0}$ mirror coated the quartz tube. After 30 minutes the coating fell off the tube. Once the Ar gas was removed, the solids floated to the bottom. The reaction was left to sit overnight. The supernatant was carefully pipetted off to avoid any product loss. The solid was transferred to a glass vial and washed with water $(100 \mathrm{~mL})$ three times. The sample was air dried before an aliquot for $\mathrm{pXRD}$ and SEM was taken. The sample was then placed back into the quartz tube and was heated to $100^{\circ} \mathrm{C}$ (at $5^{\circ} \mathrm{C} / \mathrm{min}$ ) for 2 hours, and then it ramped to $200^{\circ} \mathrm{C}\left(15^{\circ} \mathrm{C} / \mathrm{min}\right)$ where it remained for 8 hours under Ar before shutting off. The sample was removed from the quartz tube and placed into a vial for storage.

15_SKS_oxalate: Added to a quartz tube were $\mathrm{Tb}\left(\mathrm{NO}_{3}\right)_{3}(0.03 \mathrm{M}, 15 \mathrm{~mL})$ and $\mathrm{HNO}_{3}(0.1 \mathrm{M}, 45 \mathrm{~mL})$. The quartz tube was heated to $60^{\circ} \mathrm{C}$ while a constant stream of Ar was bubbling through the solution. Once the quartz tube reached $60^{\circ} \mathrm{C}$, the oxalic acid solution $(0.1 \mathrm{M}, 15 \mathrm{~mL})$ was added slowly to the quartz tube. The solution turned cloudy within seconds, and a precipitate started to form. The reaction was left to react for 1 hour while continuing to heat and bubble Ar. The tube was then removed from heat, and the hydrazine hydrate $(3 \mathrm{~mL})$ was added. The tube was returned to the bath, and the $\left(\mathrm{NH}_{3}\right)_{4} \mathrm{Pd}\left(\mathrm{NO}_{3}\right)_{2}$ (15 mL, Beantown) solution was added very slowly to avoid excess bubbling (known as foaming). Upon adding Pd the solution turned black and started to slowly bubble $\left(\mathrm{H}_{2}\right.$ gas). After $5 \mathrm{~mL}$ a $\mathrm{Pd}^{0}$ mirror coated the quartz tube. After 30 minutes the coating fell off the tube. Once the Ar gas was removed, the solids floated to the bottom. The reaction was left to sit overnight. The supernatant was carefully pipetted off to avoid any product loss. The solid was transferred to a glass vial and washed with water $(100 \mathrm{~mL})$ three times. The sample was air dried before an aliquot for pXRD and SEM was taken. The sample was then placed back into the quartz tube and was heated to $100^{\circ} \mathrm{C}$ (at $5^{\circ} \mathrm{C} / \mathrm{min}$ ) for 2 hours, and then it ramped to $200^{\circ} \mathrm{C}\left(15^{\circ} \mathrm{C} / \mathrm{min}\right)$ where is remained for 8 hours under Ar before being shut off. The sample was removed from the quartz tube and placed into a vial for storage.

16_SKS_Pdnocalc: Added to a quartz tube was $\mathrm{HNO}_{3}(0.1 \mathrm{M}, 45 \mathrm{~mL})$. The quartz tube was heated to $60^{\circ} \mathrm{C}$ while a constant stream of Ar was bubbling through the solution. Once the quartz tube reached $60^{\circ} \mathrm{C}$, the oxalic acid solution $(0.1 \mathrm{M}, 15 \mathrm{~mL})$ was added slowly to the quartz tube. The solution turned cloudy within seconds, and a precipitate started to form. The reaction was left to react for 1 hour while continuing to heat and bubble Ar. The tube was then removed from heat, and the hydrazine hydrate $(3 \mathrm{~mL})$ was added. The tube was returned to the bath, and the $\left(\mathrm{NH}_{3}\right)_{4} \mathrm{Pd}\left(\mathrm{NO}_{3}\right)_{2}(15 \mathrm{~mL}$, Beantown) solution was added very slowly to avoid excess bubbling (known as foaming). Upon adding Pd the solution turned black and started to slowly bubble $\left(\mathrm{H}_{2}\right.$ gas). After $5 \mathrm{~mL}$ a $\mathrm{Pd}^{0}$ mirror coated the quartz tube. After 30 minutes the coating fell off the tube. Once the Ar gas was removed the solids floated to the bottom. The reaction was left to sit overnight. The supernatant was carefully pipetted off to avoid any product loss. The solid was transferred to a glass vial and washed with water $(100 \mathrm{~mL})$ three times. The 
sample was air dried before an aliquot for pXRD and SEM was taken. The sample was then placed back into the quartz tube and was heated to $100^{\circ} \mathrm{C}$ (at $5^{\circ} \mathrm{C} / \mathrm{min}$ ) for 2 hours, and then it ramped to $200^{\circ} \mathrm{C}$ $\left(15^{\circ} \mathrm{C} / \mathrm{min}\right)$ where it remained for 8 hours under Ar before being shut off. The sample was removed from the quartz tube and placed into a vial for storage.

17_SKS_oxcalc: Added to a quartz tube were $\mathrm{Tb}_{4} \mathrm{O}_{7}(24.7 \mathrm{mg})$ and $\mathrm{HNO}_{3}(0.1 \mathrm{M}, 45 \mathrm{~mL})$. The quartz tube was heated to $60^{\circ} \mathrm{C}$ while a constant stream of Ar was bubbling through the solution. Once the quartz tube reached $60^{\circ} \mathrm{C}$, the oxalic acid solution $(0.1 \mathrm{M}, 15 \mathrm{~mL})$ was added slowly to the quartz tube. The solution turned cloudy within seconds, and a precipitate started to form. The reaction was left to react for 1 hour while continuing to heat and bubble Ar. The tube was then removed from heat, and the hydrazine hydrate $(3 \mathrm{~mL})$ was added. The tube was returned to the bath, and the $\left(\mathrm{NH}_{3}\right)_{4} \mathrm{Pd}\left(\mathrm{NO}_{3}\right)_{2}(15 \mathrm{~mL}$, Beantown) solution was added very slowly to avoid excess bubbling (known as foaming). Upon adding Pd the solution turned black and started to slowly bubble $\left(\mathrm{H}_{2}\right.$ gas). After $5 \mathrm{~mL}$ a $\mathrm{Pd}^{0}$ mirror coated the quartz tube. After 30 minutes the coating fell off the tube. Once the Ar gas was removed, the solids floated to the bottom. The reaction was left to sit overnight. The supernatant was carefully pipetted off to avoid any product loss. The solid was transferred to a glass vial and washed with water $(100 \mathrm{~mL})$ three times. The sample was air dried before an aliquot for pXRD and SEM was taken. The sample was then placed back into the quartz tube and was heated to $100^{\circ} \mathrm{C}$ (at $5^{\circ} \mathrm{C} / \mathrm{min}$ ) for 2 hours, and then it ramped to $200^{\circ} \mathrm{C}\left(15^{\circ} \mathrm{C} / \mathrm{min}\right)$ where it remained for 8 hours under Ar before being shut off. The gas was then switched to $\mathrm{He} / \mathrm{H}_{2}(4 \%)$, and the furnace ramped up to $700^{\circ} \mathrm{C}$ at $15^{\circ} \mathrm{C} / \mathrm{min}$ and remained there for $30 \mathrm{~min}$ before being shut off. The sample was removed from the quartz tube and placed into a vial for storage.

18_SKS_oxalate2: Added to a quartz tube were $\mathrm{Tb}\left(\mathrm{NO}_{3}\right)_{3}(0.03 \mathrm{M}, 15 \mathrm{~mL})$ and $\mathrm{HNO}_{3}(0.1 \mathrm{M}, 45 \mathrm{~mL})$. The quartz tube was heated to $60^{\circ} \mathrm{C}$ while a constant stream of Ar was bubbling through the solution. Once the quartz tube reached $60^{\circ} \mathrm{C}$, the oxalic acid solution $(0.1 \mathrm{M}, 15 \mathrm{~mL})$ was added slowly to the quartz tube. The solution turned cloudy within seconds, and a precipitate started to form. The reaction was left to react for 1 hour while continuing to heat and bubble Ar. The tube was then removed from heat, and the hydrazine hydrate $(3 \mathrm{~mL})$ was added. The tube was returned to the bath, and the $\left(\mathrm{NH}_{3}\right)_{4} \mathrm{Pd}\left(\mathrm{NO}_{3}\right)_{2}$ (15 mL, Beantown) solution was added very slowly to avoid excess bubbling (known as foaming). Upon adding Pd the solution turned black and started to slowly bubble $\left(\mathrm{H}_{2}\right.$ gas). After $5 \mathrm{~mL}$ a $\mathrm{Pd}^{0}$ mirror coated the quartz tube. After 30 minutes the coating fell off the tube. Once the Ar gas was removed, the solids floated to the bottom. The reaction was left to sit overnight. The supernatant was carefully pipetted off to avoid any product loss. The solid was transferred to a glass vial and washed with water $(100 \mathrm{~mL})$ three times. The sample was air dried before an aliquot for pXRD and SEM was taken. The sample was then placed back into the quartz tube and was heated to $100^{\circ} \mathrm{C}$ (at $5^{\circ} \mathrm{C} / \mathrm{min}$ ) for 2 hours, and then it ramped to $200^{\circ} \mathrm{C}\left(15^{\circ} \mathrm{C} / \mathrm{min}\right)$ where it remained for 8 hours under Ar before being shut off. The gas was then switched to $\mathrm{He} / \mathrm{H}_{2}(4 \%)$, and the furnace ramped up to $700^{\circ} \mathrm{C}$ at $15^{\circ} \mathrm{C} / \mathrm{min}$ where it remained for $30 \mathrm{~min}$ before being shut off. The sample was removed from the quartz tube and placed into a vial for storage.

20_SKS_Pd: Added to a quartz tube were $\mathrm{Tb}\left(\mathrm{NO}_{3}\right)_{3}(0.03 \mathrm{M}, 15 \mathrm{~mL})$ and $\mathrm{HNO}_{3}(0.1 \mathrm{M}, 45 \mathrm{~mL})$. The quartz tube was heated to $60^{\circ} \mathrm{C}$ while a constant stream of Ar was bubbling through the solution. Once the quartz tube reached $60^{\circ} \mathrm{C}$, the oxalic acid solution $(0.1 \mathrm{M}, 15 \mathrm{~mL})$ was added slowly to the quartz tube. The solution turned cloudy within seconds, and a precipitate started to form. The reaction was left to react for 1 hour while continuing to heat and bubble Ar. The tube was then removed from heat, and the hydrazine hydrate $(3 \mathrm{~mL})$ was added. The tube was returned to the bath, and the $\left(\mathrm{NH}_{3}\right)_{4} \mathrm{Pd}\left(\mathrm{NO}_{3}\right)_{2}(15 \mathrm{~mL}$, Beantown) solution was added very slowly to avoid excess bubbling (known as foaming). Upon adding Pd the solution turned black and started to slowly bubble $\left(\mathrm{H}_{2}\right.$ gas). After $5 \mathrm{~mL}$ a $\mathrm{Pd}^{0}$ mirror coated the quartz tube. After 30 minutes the coating fell off the tube. Once the Ar gas was removed, the solids floated to the bottom. The reaction was left to sit overnight. The supernatant was carefully pipetted off to avoid any product loss. The solid was transferred to a glass vial and washed with water $(100 \mathrm{~mL})$ three times. The sample was air dried before an aliquot for pXRD and SEM was taken. The sample was then 
placed back into the quartz tube and was heated to $100^{\circ} \mathrm{C}$ (at $5^{\circ} \mathrm{C} / \mathrm{min}$ ) for 2 hours, and then it ramped to $200^{\circ} \mathrm{C}\left(15^{\circ} \mathrm{C} / \mathrm{min}\right)$ where it remained for 8 hours under Ar before being shut off. The gas was then switched to $\mathrm{He} / \mathrm{H}_{2}(4 \%)$, and the furnace ramped up to $700^{\circ} \mathrm{C}$ at $15^{\circ} \mathrm{C} / \mathrm{min}$ where it remained for $30 \mathrm{~min}$ before being shut off. The sample was removed from the quartz tube and placed into a vial for storage.

21_SKS_Pd: Added to a quartz tube were $\mathrm{Tb}\left(\mathrm{NO}_{3}\right)_{3}(0.03 \mathrm{M}, 15 \mathrm{~mL})$ and $\mathrm{HNO}_{3}(0.1 \mathrm{M}, 45 \mathrm{~mL})$. The quartz tube was heated to $60^{\circ} \mathrm{C}$ while a constant stream of Ar was bubbling through the solution. Once the quartz tube reached $60^{\circ} \mathrm{C}$, the oxalic acid solution $(0.1 \mathrm{M}, 15 \mathrm{~mL})$ was added slowly to the quartz tube. The solution turned cloudy within seconds, and a precipitate started to form. The reaction was left to react for 1 hour while continuing to heat and bubble Ar. The tube was then removed from heat, and the hydrazine hydrate $(2 \mathrm{~mL})$ was added. The tube was returned to the bath, and the $\left(\mathrm{NH}_{3}\right)_{4} \mathrm{Pd}\left(\mathrm{NO}_{3}\right)_{2}(15 \mathrm{~mL}$, Beantown) solution was added very slowly to avoid excess bubbling (known as foaming). Upon adding Pd the solution turned black and started to slowly bubble $\left(\mathrm{H}_{2}\right.$ gas $)$. After $5 \mathrm{~mL}$ a $\mathrm{Pd}^{0}$ mirror coated the quartz tube. After 30 minutes the coating fell off the tube. Once the Ar gas was removed, the solids floated to the bottom. The reaction was left to sit overnight. The supernatant was carefully pipetted off to avoid any product loss. The solid was transferred to a glass vial and washed with water $(100 \mathrm{~mL})$ three times. The sample was air dried before an aliquot for pXRD and SEM was taken. The sample was then placed back into the quartz tube and was heated to $100^{\circ} \mathrm{C}$ (at $5^{\circ} \mathrm{C} / \mathrm{min}$ ) for 2 hours, and then it ramped to $200^{\circ} \mathrm{C}\left(15^{\circ} \mathrm{C} / \mathrm{min}\right)$ where it remained for 8 hours under Ar before being shut off. The gas was then switched to $\mathrm{He} / \mathrm{H}_{2}(4 \%)$, and the furnace ramped up to $700^{\circ} \mathrm{C}$ at $15^{\circ} \mathrm{C} / \mathrm{min}$ where it remained for $30 \mathrm{~min}$ before being shut off. The sample was removed from the quartz tube and placed into a vial for storage.

22_SKS_Pd: Added to a quartz tube were $\mathrm{Tb}\left(\mathrm{NO}_{3}\right)_{3}(0.03 \mathrm{M}, 15 \mathrm{~mL})$ and $\mathrm{HNO}_{3}(0.1 \mathrm{M}, 45 \mathrm{~mL})$. The quartz tube was heated to $60^{\circ} \mathrm{C}$ while a constant stream of Ar was bubbling through the solution. Once the quartz tube reached $60^{\circ} \mathrm{C}$, the oxalic acid solution $(0.1 \mathrm{M}, 15 \mathrm{~mL})$ was added slowly to the quartz tube. The solution turned cloudy within seconds, and a precipitate started to form. The reaction was left to react for 1 hour while continuing to heat and bubble Ar. The tube was then removed from heat, and the hydrazine hydrate $(1 \mathrm{~mL})$ was added. The tube was returned to the bath, and the $\left(\mathrm{NH}_{3}\right)_{4} \mathrm{Pd}\left(\mathrm{NO}_{3}\right)_{2}(15 \mathrm{~mL}$, Beantown) solution was added very slowly to avoid excess bubbling (known as foaming). Upon adding $\mathrm{Pd}$ the solution turned black and started to slowly bubble $\left(\mathrm{H}_{2}\right.$ gas). After $5 \mathrm{~mL}$ a $\mathrm{Pd}^{0}$ mirror coated the quartz tube. After 30 minutes the coating fell off the tube. Once the Ar gas was removed, the solids floated to the bottom. The reaction was left to sit overnight. The supernatant was carefully pipetted off to avoid any product loss. The solid was transferred to a glass vial and washed with water $(100 \mathrm{~mL})$ three times. The sample was air dried before an aliquot for pXRD and SEM was taken. The sample was then placed back into the quartz tube and was heated to $100^{\circ} \mathrm{C}$ (at $5^{\circ} \mathrm{C} / \mathrm{min}$ ) for 2 hours, and then it ramped to $200^{\circ} \mathrm{C}\left(15^{\circ} \mathrm{C} / \mathrm{min}\right)$ where it remained for 8 hours under Ar before being shut off. The gas was then switched to $\mathrm{He} / \mathrm{H}_{2}(4 \%)$, and the furnace ramped up to $700^{\circ} \mathrm{C}$ at $15^{\circ} \mathrm{C} / \mathrm{min}$ where it remained for $30 \mathrm{~min}$ before being shut off. The sample was removed from the quartz tube and placed into a vial for storage.

23_SKS_Pdstem: Added to a quartz tube were $\mathrm{Tb}\left(\mathrm{NO}_{3}\right)_{3}(0.03 \mathrm{M}, 10 \mathrm{~mL})$ and $\mathrm{HNO}_{3}(0.1 \mathrm{M}, 45 \mathrm{~mL})$. The quartz tube was heated to $60^{\circ} \mathrm{C}$ while a constant stream of Ar was bubbling through the solution. Once the quartz tube reached $60^{\circ} \mathrm{C}$, the oxalic acid solution $(0.1 \mathrm{M}, 15 \mathrm{~mL})$ was added slowly to the quartz tube. The solution turned cloudy within seconds, and a precipitate started to form. The reaction was left to react for 1 hour while continuing to heat and bubble Ar. The tube was then removed from heat, and the hydrazine hydrate $(3 \mathrm{~mL})$ was added. The tube was returned to the bath, and the $\left.\left(\mathrm{NH}_{3}\right)_{4} \mathrm{Pd}_{(} \mathrm{NO}_{3}\right)_{2}$ (10 g, Strem) solution was added very slowly to avoid excess bubbling (known as foaming). Upon adding $\mathrm{Pd}$ the solution turned black and started to slowly bubble $\left(\mathrm{H}_{2}\right.$ gas). After $5 \mathrm{~mL}$ a $\mathrm{Pd}^{0}$ mirror coated the quartz tube. After 30 minutes the coating fell off the tube. Once the Ar gas was removed, the solids floated to the bottom. The reaction was left to sit overnight. The supernatant was carefully pipetted off to avoid any product loss. The solid was transferred to a glass vial and washed with water $(100 \mathrm{~mL})$ three times. The sample was air dried before an aliquot for pXRD and SEM was taken. The sample was then 
placed back into the quartz tube and was heated to $100^{\circ} \mathrm{C}$ (at $5^{\circ} \mathrm{C} / \mathrm{min}$ ) for 2 hours, and then it ramped to $200^{\circ} \mathrm{C}\left(15^{\circ} \mathrm{C} / \mathrm{min}\right)$ where it remained for 8 hours under Ar before being shut off. The gas was then switched to $\mathrm{He} / \mathrm{H}_{2}(4 \%)$, and the furnace ramped up to $700^{\circ} \mathrm{C}$ at $15^{\circ} \mathrm{C} / \mathrm{min}$ where it remained for $30 \mathrm{~min}$ before being shut off. The sample was removed from the quartz tube and placed into a vial for storage.

24_SKS_PdK2PdCl4: Added to a quartz tube were $\mathrm{Tb}\left(\mathrm{NO}_{3}\right)_{3}(0.03 \mathrm{M}, 1.6 \mathrm{~mL})$ and $\mathrm{HNO}_{3}(0.1 \mathrm{M}$, $30 \mathrm{~mL})$. The quartz tube was heated to $60^{\circ} \mathrm{C}$ while a constant stream of Ar was bubbling through the solution. Once the quartz tube reached $60^{\circ} \mathrm{C}$, the oxalic acid solution $(0.1 \mathrm{M}, 15 \mathrm{~mL})$ was added slowly to the quartz tube. The solution turned cloudy within seconds, and a precipitate started to form. The reaction was left to react for 1 hour while continuing to heat and bubble Ar. The tube was then removed from heat, and the hydrazine hydrate $(3 \mathrm{~mL})$ was added. The tube was returned to the bath, and the $\mathrm{K}_{2} \mathrm{PdCl}_{4}(618.2$ mg, Sigma Aldrich) solution was added very slowly to avoid excess bubbling (known as foaming). Upon adding Pd the solution turned black and started to slowly bubble $\left(\mathrm{H}_{2}\right.$ gas $)$. After $5 \mathrm{~mL}$ a $\mathrm{Pd}^{0}$ mirror coated the quartz tube. After 30 minutes the coating fell off the tube. Once the Ar gas was removed, the solids floated to the bottom. The reaction was left to sit overnight. The supernatant was carefully pipetted off to avoid any product loss. The solid was transferred to a glass vial and washed with water $(100 \mathrm{~mL})$ three times. The sample was air dried before an aliquot for pXRD and SEM was taken. The sample was then placed back into the quartz tube and was heated to $100^{\circ} \mathrm{C} \mathrm{(at} 5^{\circ} \mathrm{C} / \mathrm{min}$ ) for 2 hours, and then it ramped to $200{ }^{\circ} \mathrm{C}\left(15^{\circ} \mathrm{C} / \mathrm{min}\right)$ where it remained for 8 hours under Ar before being shut off. The gas was then switched to $\mathrm{He} / \mathrm{H}_{2}(4 \%)$, and the furnace ramped up to $700^{\circ} \mathrm{C}$ at $15^{\circ} \mathrm{C} / \mathrm{min}$ where it remained for $30 \mathrm{~min}$ before being shut off off. The sample was removed from the quartz tube and placed into a vial for storage. 
